\title{
mRNA-Based Nanomedicinal Products to Address Corneal Inflammation by Interleukin-10 Supplementation
}

\author{
Itziar Gómez-Aguado ${ }^{1,2} \mathbb{D}$, Julen Rodríguez-Castejón ${ }^{1,2} \mathbb{D}$, Marina Beraza-Millor ${ }^{1,2}$, Mónica Vicente-Pascual ${ }^{1} \mathbb{D}$, \\ Alicia Rodríguez-Gascón ${ }^{1,2}$ (D), Sara Garelli ${ }^{3}$, Luigi Battaglia ${ }^{3}$ (D), Ana del Pozo-Rodríguez ${ }^{1,2, *(D)}$ \\ and María Ángeles Solinís 1,2,*(D)
}

1 Pharmacokinetic, Nanotechnology and Gene Therapy Group (PharmaNanoGene), Faculty of Pharmacy, Centro de Investigación Lascaray Ikergunea, University of the Basque Country UPV/EHU, Paseo de la Universidad 7, 01006 Vitoria-Gasteiz, Spain; itziar.gomez@ehu.eus (I.G.-A.); julen.rodriguez@ehu.eus (J.R.-C.); marina.beraza@ehu.eus (M.B.-M.); monica.vicente@ehu.eus (M.V.-P.); alicia.rodriguez@ehu.eus (A.R.-G.)

2 Bioaraba, Microbiology, Infectious Disease, Antimicrobial Agents, and Gene Therapy, 01006 Vitoria-Gasteiz, Spain

3 Dipartimento di Scienza e Tecnologia del Farmaco, Università degli Studi di Torino, Via Pietro Giuria 9, 10125 Torino, Italy; saragarelli.sg@gmail.com (S.G.); luigi.battaglia@unito.it (L.B.)

* Correspondence: ana.delpozo@ehu.eus (A.d.P.-R.); marian.solinis@ehu.eus (M.Á.S.); Tel.: +34-945-014-498 (A.d.P.-R.); +34-945-013-469 (M.Á.S.)

check for updates

Citation: Gómez-Aguado, I.; Rodríguez-Castejón, J.; Beraza-Millor, M.; Vicente-Pascual, M.; Rodríguez-Gascón, A.; Garelli, S.; Battaglia, L.; del Pozo-Rodríguez, A.; Solinís, M.Á. mRNA-Based

Nanomedicinal Products to Address Corneal Inflammation by Interleukin-10 Supplementation. Pharmaceutics 2021, 13, 1472. https:// doi.org/10.3390/pharmaceutics 13091472

Academic Editor: Alf Lamprecht

Received: 26 July 2021

Accepted: 11 September 2021

Published: 15 September 2021

Publisher's Note: MDPI stays neutral with regard to jurisdictional claims in published maps and institutional affiliations.

Copyright: (c) 2021 by the authors. Licensee MDPI, Basel, Switzerland. This article is an open access article distributed under the terms and conditions of the Creative Commons Attribution (CC BY) license (https:// creativecommons.org/licenses/by/ $4.0 /)$.

\begin{abstract}
The anti-inflammatory cytokine Interleukin-10 (IL-10) is considered an efficient treatment for corneal inflammation, in spite of its short half-life and poor eye bioavailability. In the present work, mRNA-based nanomedicinal products based on solid lipid nanoparticles (SLNs) were developed in order to produce IL-10 to treat corneal inflammation. mRNA encoding green fluorescent protein (GFP) or human IL-10 was complexed with different SLNs and ligands. After, physicochemical characterization, transfection efficacy, intracellular disposition, cellular uptake and IL-10 expression of the nanosystems were evaluated in vitro in human corneal epithelial (HCE-2) cells. Energy-dependent mechanisms favoured HCE-2 transfection, whereas protein production was influenced by energyindependent uptake mechanisms. Nanovectors with a mean particle size between 94 and $348 \mathrm{~nm}$ and a positive superficial charge were formulated as eye drops containing $1 \%(w / v)$ of polyvinyl alcohol (PVA) with 7.1-7.5 pH. After three days of topical administration to mice, all formulations produced GFP in the corneal epithelium of mice. SLNs allowed the obtaining of a higher transfection efficiency than naked mRNA. All formulations produce IL-10, and the interleukin was even observed in the deeper layers of the epithelium of mice depending on the formulation. This work shows the potential application of mRNA-SLN-based nanosystems to address corneal inflammation by gene augmentation therapy.
\end{abstract}

Keywords: messenger RNA; solid lipid nanoparticles; interleukin-10; corneal inflammation; polyvinyl alcohol; topical administration; gene augmentation; transfection; corneal epithelium; advanced therapies

\section{Introduction}

The eye is considered the perfect target for gene therapy due to its physiological features: it is easy to access and examine, it has a well-defined anatomy and it is relatively immune privileged. Moreover, from an experimental point of view, in the same subject, one eye can be used as a control, whereas the other eye can be used as the experimental target [1-3]. Currently, 47 clinical trials restricted to "ocular diseases" are registered in the database of Gene Therapy Clinical Trials Worldwide [4], all of them targeting retinal degenerative diseases, except one, which concerns corneal opacity. The cornea is a transparent tissue localized in the anterior segment of the eye, which contributes to eyesight by focusing a visual image through light refraction. Several factors can damage this tissue and provoke corneal inflammation or keratitis, such as infections, dry eye, eyelid 
disorders, physical and chemical damage, and a wide variety of underlying diseases [5]. Current treatments of corneal inflammation are based on corticosteroids, which require repeated topical applications and have been associated with multiple adverse effects, such as infectious keratitis, increased intraocular pressure, and cataracts [6]. Alternatively, the topical administration of IL-10, an anti-inflammatory cytokine, has been suggested as an effective treatment for corneal inflammation [7]. However, the short half-life and poor eye bioavailability of IL-10 limit its therapeutic use. Therefore, IL-10 ocular delivery may be better attempted by gene therapy, with the aim of inducing IL-10 de novo synthesis in corneal cells [8].

In the last few decades, a wide range of reagents and techniques suitable to transfer nucleic acids into cells have been developed, in order to modulate both in vitro and in vivo gene expression. Particularly, mRNA therapeutics present several advantages: since mRNA does not need to enter inside the cell nucleus in order to exert its effect, protein translation is faster than in the case of DNA; furthermore, mRNA expression is temporary and it owns a safe profile with no risk of insertion-related mutagenesis, as it does not incorporate into the genome of the host [9]. Additionally, the production and manufacturing of mRNA is easy to scale up in a cost-effective, standardized, and reproducible way. However, mRNA instability is one of its major vulnerabilities [10], which makes the development of suitable delivery systems necessary. Delivery systems should be able to protect mRNA against RNase degradation, and to ensure its intracellular delivery inside the cytoplasm of the target cell [11]. In this context, different strategies and efforts for advances in nanotechnology and material sciences are still ongoing [9]. Presently, non-viral vectors are at the frontline of mRNA therapy, in contrast to DNA-based gene therapy; particularly, lipid-based vectors are among the most extensively used non-viral nucleic acid delivery platforms. Indeed, mRNA therapy has gained much attention after its application in the vaccination against the SARS-CoV-2 [12-14]. It should be noted that during the COVID-19 pandemic, the first vaccines approved for distribution and use against the SARS-CoV-2 by the European Medicines Agency (EMA) and the United States Food and Drug Administration (FDA) were based on mRNA encapsulated in lipid nanoparticles (LNs) $[15,16]$. These mRNA vaccines have been well-tolerated and have demonstrated approximately $95 \%$ efficacy against COVID-19, with few adverse events [17,18].

Among lipid-based systems, liposomes and solid lipid nanoparticles (SLNs) have been suggested as up-and-coming non-viral ocular drug delivery systems. [19,20]. Liposomes were introduced as carriers for the delivery of nucleic acids for gene therapy over two decades ago and, to date, they still represent the most widely studied vectors for gene delivery. Liposomes used for gene delivery are typically nanometric and are defined by a spherical vesicle with an aqueous internal cavity enclosed by a lipid bilayer membrane. However, these systems are not devoid of stability and efficacy issues [21,22]. SLNs were more recently developed with the aim of, among other things, addressing the above issues underlying liposome gene transfection [23]. SLNs are spherical particles with a solid lipid core matrix, which is stabilized by surfactants in an aqueous dispersion, and are usually composed of well-tolerated physiological lipids [24-27]. In addition, SLNs have demonstrated to be effective for ocular topical drug administration [28]. This administration route shows several advantages: it is non-invasive, drug absorption into the systemic circulation is minimized, first pass metabolism is prevented, and formulations are easy to administer. However, the main issue of conventional ocular drug delivery systems relies on the poor retention onto the ocular surface, due to corneal clearance; as a consequence, the amount of drug that is able to cross the cornea and access the ocular structures is small. Therefore, an effective ocular drug delivery system should increase corneal retention time and improve drug permeation through the cornea [29]. SLNs possess a nanometer sized-range, lipophilic properties, and usually positive surface charges. This makes them suitable for topical drug administration by improving corneal permeation and retention [30,31]. Previously, our research group has used a gene augmentation strategy to induce IL-10 production into the cornea by the administration of SLNs containing plasmid 
DNA (pDNA) [32]. However, mRNA could be an alternative therapeutic option to tackle corneal inflammation, thanks to its high efficacy, safety profile, and versatility for fast protein production.

The aim of this experimental work is the development of SLNs containing mRNA as non-viral vectors, to be used as a genetic supplementation strategy for the de novo production of IL-10 in corneal cells. Additionally, vectors prepared with plasmid DNA (pDNA) were evaluated for comparison purposes. Formulations containing mRNA or pDNA encoding green fluorescent protein (GFP) or IL-10 were characterized from a physicochemical point of view, and then evaluated for internalization and transfection properties, both in vitro by using human corneal epithelial (HCE-2), and in vivo after administration to mice by ocular instillation.

\section{Materials and Methods}

\subsection{Materials}

1,2-Dioleoyl-3-trimethylammonium-propane chloride salt (DOTAP) was obtained from Avanti Polar-lipids, Inc. (Alabaster, AL, USA). Precirol ${ }^{\circledR}$ ATO 5 (glyceryl palmitostearate) was kindly provided by Gattefossé (Madrid, Spain). Tween 80 and dichloromethane were purchased from Panreac (Madrid, Spain) and sodium behenate from Nu-Chek Prep (Eleysian, AL, USA). Sigma-Aldrich (Madrid, Spain) provided protamine sulfate salt from salmon (Grade X) (P), dextran (Mn of 3260 Da) (DX), DEAE-dextran, Nile Red and partially hydrolyzed polyvinyl alcohol (PVA) 9000-10,000 Da $\mathrm{M}_{w}$. Lifecore Biomedical (Chaska, MN, USA) supplied hyaluronic acid (HA) $\left(\mathrm{M}_{w}\right.$ of $\left.100 \mathrm{KDa}\right)$.

CleanCap ${ }^{\mathrm{TM}}$ EGFP mRNA (5moU) and CleanCap ${ }^{\mathrm{TM}}$ Cyanine 5 EGFP mRNA (5moU were acquired from TriLink BioTechnologies (San Diego, CA, USA). Both of the nucleic acids encode green fluorescent protein (GFP). mRNA encoding human IL-10 was customized by TriLink BioTechnologies. Professor BHF Weber laboratory (University of Regensburg, Germany) kindly provided plasmid pcDNA3-EGFP (6.1 kb) encoding GFP. Plasmid pUNO1-hIL10 (3.7 kb), which encodes human IL-10, was acquired by InvivoGen (San Diego, CA, USA). Label IT ${ }^{\circledR} \mathrm{Cy}^{\circledR} 5$ Nucleic Acid Labeling Kit was obtained from Mirus Bio (Madison, WI, USA).

Materials used on agarose gel in an electrophoresis assay were acquired from Bio-Rad (Madrid, Spain). Ambion ${ }^{\mathrm{TM}}$ RNase I was purchased from Life Technologies (Thermo Fisher Scientific, Madrid, Spain), Deoxyribonuclease I (DNase I) and sodium dodecyl sulfate (SDS) from Sigma-Aldrich and GelRed ${ }^{\mathrm{TM}}$ from Biotium (Fremont, CA, USA).

Human Corneal Epithelial (HCE-2) cells were purchased from American Type Culture Collection (ATCC, Manassas, VA, USA). Cell culture reagents, including Dulbecco's Modified Eagle's Medium/Nutrient Mixture F-12 with GlutaMAX ${ }^{\text {TM }}$ (DMEM/F-12 with GlutaMAX ${ }^{\mathrm{TM}}$ ), fetal bovine serum (FBS), Penicillin-Streptomycin, Trypsin/EDTA and Attachment Factor were acquired from Life Technologies (Thermo Fisher Scientific, Madrid, Spain), whereas epidermal Growth Factor (EGF) and human insulin solution were obtained from Myltenyi Biotec (Madrid, Spain) and Sigma-Aldrich (Madrid, Spain), respectively. The DuoSet Ancillary reagent kit and Enzyme-linked immunoassay (ELISA) for IL-10 were obtained from R\&D Systems (Minneapolis, MN, USA).

Reporter lysis buffer was provided by Promega Biotech Ibérica (Madrid, Spain). Paraformaldehyde (PFA) was obtained from Panreac, while 40,6-diamidine-20-phenylindole dihydrochloride (DAPI)-fluoromount-G was purchased from Southern Biotech (Birmingham, AL, USA). Phosphate buffered saline (PBS) and HEPES buffered solution were obtained from Gibco (Thermo Fisher Scientific, Madrid, Spain) and Lipofectamine ${ }^{\mathrm{TM}}$ 2000 Lipid-Reagent was acquired from Life Technologies (Thermo Fisher Scientific, Madrid, Spain). The 7-Amino-Actinomycin D (7-AAD) Viability Dye was acquired from Beckman Coulter (Brea, CA, USA).

Antibodies used for immunoassay, Anti-GFP polyclonal antibody and goat anti-Rabbit IgG (H+L) Cross-Adsorbed Secondary Antibody Alexa Fluor 488, were provided by Life Technologies (Thermo Fisher Scientific, Madrid, Spain), except rabbit Anti-IL-10 antibody, 
which was obtained from Abcam (Cambridge, UK). Sakura Finetek Europe (Alphen aan den Rijn, The Netherlands) supplied Tissue-Tek ${ }^{\circledR}$ O.C.T.-compound.

Other chemicals, unless detailed, were reagent grade from Panreac (Barcelona, Spain) and Sigma-Aldrich (Madrid, Spain).

\subsection{Formulation of SLNs and Vectors}

Three different techniques were used in order to prepare SLNs: solvent evaporation/emulsification $\left(\mathrm{SLN}_{\mathrm{EE}}\right)$, hot-melt emulsification $\left(\mathrm{SLN}_{\mathrm{HM}}\right)$ and coacervation $\left(\mathrm{SLN}_{\mathrm{C}}\right)$.

$\mathrm{SLN}_{\mathrm{EE}}$ were elaborated as previously reported [33], with the solid lipid Precirol ${ }^{\circledR}$ ATO 5 and the cationic lipid DOTAP, stabilized by the surfactant Tween 80 . Briefly, SLN $\mathrm{EE}_{\mathrm{EE}}$ were obtained by the sonication (Branson Sonifier 250, Danbury) of the organic phase (Precirol ${ }^{\circledR}$ ATO 5 dissolved in dichloromethane $5 \% w / v)$ in the aqueous phase, containing the cationic lipid DOTAP $(0.4 \% w / v)$ and Tween $80(0.1 \% w / v)$. SLNs' precipitation occurred upon dichloromethane evaporation.

$\mathrm{SLN}_{\mathrm{HM}}$ was produced as a SLN $\mathrm{EE}_{\mathrm{EE}}$ with minor modifications. Briefly, DOTAP $(0.4 \%$ $w / v)$ and Tween $80(0.1 \% w / v)$ were dissolved in water. This aqueous solution and Precirol ${ }^{\circledR}$ ATO 5 were heated in a bain-marie. When both phases were led to $80^{\circ} \mathrm{C}$ and lipids melted, the aqueous solution was added to the Precirol ${ }^{\circledR}$ ATO 5. The emulsion was obtained by sonication (Branson Sonifier 250, Danbury, CT, USA) for $30 \mathrm{~min}$ at $50 \mathrm{~W}$. SLNs were obtained by cooling the obtained nanoemulsion on ice for $30 \mathrm{~min}$.

SLN $_{C}$ were composed of behenic acid as the lipid matrix, coated by the suspending agent PVA 9000 and the cationizing agent DEAE-dextran, as previously described [32]. Briefly, sodium behenate and PVA 9000 were dissolved in water under hot agitation, and when the solution reached $80^{\circ} \mathrm{C}$ and became translucent, $\mathrm{NaOH}$ was added. Then, when the solution turned completely transparent DEAE-dextran was added drop by drop, turning the mixture turbid. Later, $\mathrm{HCl}$ was rapidly added and when the suspension turned white, it was cooled under stirring in a water bath. The final product underwent a re-melting process, by heating again and cooling by agitation in a water bath.

When required, Nile Red was incorporated in the preparation of all SLNs to label them. In the case of SLN $\mathrm{EE}_{\mathrm{EE}}$, Nile Red was dissolved in the dichloromethane of the organic phase, whereas in $\mathrm{SLN}_{\mathrm{HM}}$ Nile Red was dissolved in dichloromethane and added during the first $30 \mathrm{~s}$ of the sonication step. Finally, in the case of $\mathrm{SLN}_{\mathrm{C}}$, a solution of dichloromethane containing Nile Red was added during the re-melting step.

In order to prepare SLN-based vectors, an aqueous solution of protamine $(\mathrm{P})$ was added to the nucleic acid, mRNA or pDNA. Then, a solution of polysaccharide, dextran (DX) or hyaluronic acid (HA) dissolved in water was added. Finally, the SLN suspension was added to the previous complexes and incubated for $20 \mathrm{~min}$. Electrostatic interactions between negative and positive charges of the components led to the formation of the final vectors, in which complexes were adsorbed on the surface of the cationic SLNs.

The weight ratios of the components of the formulations are summarized in Table 1.

Table 1. Weight ratios of the formulations.

\begin{tabular}{|c|c|}
\hline Name of the Vector & Weight Ratio \\
\hline mRNA-DX-SLN ${ }_{\mathrm{EE}}$ & DX:P:mRNA:SLN ${ }_{\mathrm{EE}}$ 1:0.25:1:5 \\
\hline mRNA-HA-SLN ${ }_{\mathrm{EE}}$ & HA:P:mRNA:SLN ${ }_{\mathrm{EE}}$ 0.5:0.5:1:5 \\
\hline mRNA-DX-SLN & DX:P:mRNA:SLN ${ }_{\mathrm{HM}}$ 1:0.25:1:5 \\
\hline mRNA-HA-SLN $_{\mathrm{HM}}$ & HA:P:mRNA:SLN ${ }_{\mathrm{HM}}$ 0.5:0.5:1:5 \\
\hline mRNA-SLN ${ }_{C}$ & P:mRNA:SLN ${ }_{C}$ 2:1:10 \\
\hline mRNA-HA-SLN $_{C}$ & HA:P:mRNA:SLN ${ }_{C}$ 0.5:2:1:10 \\
\hline pDNA-DX-SLN $\mathrm{HM}$ & DX:P:pDNA:SLN ${ }_{\mathrm{HM}}$ 1:2:1:5 \\
\hline pDNA-HA-SLN & HA:P:pDNA:SLN ${ }_{\mathrm{HM}}$ 0.5:2:1:5 \\
\hline
\end{tabular}

SLN: Solid Lipid Nanoparticle. DX: dextran. HA: hyaluronic acid. P: protamine. 
In order to obtain viscous formulations suitable for ocular delivery to animal models, an aqueous solution of PVA $\left(85,000-124,000 \mathrm{M}_{w}\right)$ was incorporated into the above mentioned vectors. The final concentration of PVA was $1 \%(w / v)$.

\subsection{Characterization of SLNs and Vectors: Size, Polydispersity Index and $\zeta$-Potential Measurements}

The mean size and polydispersity index (PDI) of 3 batches of SLNs and vectors were measured by Dynamic Light Scattering (DLS) and $\zeta$-potential was determined by Laser Doppler Velocimetry (LDP). These measurements were carried out in a ZetaSizer Nano ZS (Malvern Panalytical, Malvern, UK) after the appropriate dilution of the samples in Milli- $\mathrm{Q}^{\mathrm{TM}}$ water (EDM Millipore, MA, USA).

\subsection{Agarose Gel Electrophoresis Assay}

Studies of mRNA binding capacity, protection from RNase I digestion and release from the vectors were performed in a 1.2\% agarose gel electrophoresis labelled with Gel $\operatorname{Red}^{\mathrm{TM}}$. The gel ran for $60 \mathrm{~min}$ at $75 \mathrm{~V}$, then it was immediately analyzed with the Uvitec Uvidoc D-55-LCD-20 M Auto transilluminator (Cambridge, UK). In order to evaluate binding capacity, vectors were diluted in MilliQ ${ }^{\mathrm{TM}}$ water to a final concentration of $0.12 \mu \mathrm{g}$ $\mathrm{mRNA} / \mu \mathrm{L}$ in the gel. Protection from RNase I digestion was analyzed by the addition of $6 \mathrm{U}$ RNase I/ $\mu \mathrm{g}$ mRNA; mixtures were incubated at $37^{\circ} \mathrm{C}$ for $40 \mathrm{~min}$ in a heater. Then, the samples were removed from the heater and mixed with an SDS solution (final concentration of $1 \%$ ), at room temperature. The same SDS solution was added to the vectors to unbind the mRNA in the release studies. Two controls for the integrity of the mRNA were included in the assay: RiboRuler High Range RNA Ladder and untreated CleanCap ${ }^{\mathrm{TM}}$ EGFP mRNA (5moU).

In order to study the pDNA binding capacity, protection against DNase I digestion and release from the vectors, $0.7 \%$ agarose gel electrophoresis with Gel $\operatorname{Red}^{\mathrm{TM}}$ was used. The gel was analyzed with the Uvitec Uvidoc D-55-LCD-20 M Auto transilluminator (Cambridge, UK) after running for $30 \mathrm{~min}$ at $120 \mathrm{~V}$. The binding capacity was evaluated by adding vectors diluted in MilliQ ${ }^{\mathrm{TM}}$ water to a final concentration of $0.03 \mu \mathrm{g} \mathrm{pDNA} / \mu \mathrm{L}$ in the gel. For DNAse I protection, the same concentration was exposed to $1 \mathrm{U}$ DNase $\mathrm{I} / 2.5 \mu \mathrm{g}$ pDNA and then incubated at $37^{\circ} \mathrm{C}$ for $30 \mathrm{~min}$ in a heater. The samples were removed from the heater and mixed with an SDS solution (4\%) to a final concentration of $1 \%$ at room temperature. The same SDS solution was added to the vectors to unbind the plasmid in the release studies. Two controls for the integrity of the pDNA were included in the gels: $1 \mathrm{~kb}$ pDNA ladder from NIPPON Genetics Europe (Dueren, Germany) and untreated pcDNA3-EGFP plasmid.

\section{5. $\mathrm{pH}$ Measurement}

Crison Basic $20 \mathrm{pH}$ meter (Crison Instruments, Barcelona, Spain) was employed to determine the $\mathrm{pH}$ of the vectors. Measures were carried out in triplicate and the $\mathrm{pH}$ meter was calibrated daily.

\subsection{Cell Culture Studies}

Human corneal epithelial (HCE-2) cell line was used in order to perform in vitro studies. HCE-2 cell line was maintained in a DMEM/F-12 GlutaMAX ${ }^{\mathrm{TM}}$ medium, which was supplemented with $15 \%(v / v)$ heat-inactivated fetal bovine serum (FBS), insulin $(4 \mathrm{mg} / \mathrm{mL})$, Epidermal Growth Factor (EGF) $(10 \mathrm{ng} / \mathrm{mL})$, and Penicillin-Streptomycin $(1 \%$ $v / v$ ) and incubated at $37{ }^{\circ} \mathrm{C}$ with $5 \% \mathrm{CO}_{2}$. Cells were sub-cultured once a week using Trypsin/EDTA in flasks earlier treated with Attachment Factor. The medium was renewed every 2 days. Cells from passages 1 to 4 were used to perform all in vitro assays. 


\subsubsection{Transfection Efficacy and Cell Viability}

mRNA-based vectors were prepared $72 \mathrm{~h}$ before their addition and maintained at $4{ }^{\circ} \mathrm{C}$ before their use.

After incubation with Attachment Factor, the cells were cultured on 24-well plates for $72 \mathrm{~h}$ at a density of 70,000 cells/well, until the cells were adhered and were able to create a monolayer. Later, part of the medium was removed, leaving enough volume to cover the cells, and a total volume of $75 \mu \mathrm{L}$ of each vector diluted in Hank's Balanced Salt solution (HBS) (equivalent to $2.5 \mu \mathrm{g}$ ) was added to each well for $4 \mathrm{~h}$ in the incubator at $37^{\circ} \mathrm{C}$ in a $5 \% \mathrm{CO}_{2}$. The medium containing the vectors was removed after the incubation time, and the cells were refreshed with $1 \mathrm{~mL}$ of the complete medium. The cells were kept growing during $48 \mathrm{~h}$ or $72 \mathrm{~h}$ in the case of mRNA- or pDNA-vectors, respectively.

The percentage of transfected cells and intensity of fluorescence, indicative of the amount of GFP produced, as well as cell viability, were measured using a CytoFLEX flow cytometer (Beckman Coulter). For this purpose, the cells were washed with $500 \mu \mathrm{L}$ of PBS and then detached by incubation with $300 \mu \mathrm{L}$ of Trypsin/EDTA for $5 \mathrm{~min}$. After the centrifugation of cell suspension at $1000 \mathrm{rpm}$ for $5 \mathrm{~min}$, the supernatant was removed, and the pellet of cells was resuspended in $500 \mu \mathrm{L}$ of PBS. Ten thousand events were collected for each sample. Transfection efficacy was measured at $525 \mathrm{~nm}$ (FITC) [34], and cell viability was determined at $610 \mathrm{~nm}$ (ECD), after the addition of 7-Amino-Actinomycin D (7-AAD) Viability Dye to the samples. The percentage of transfected cells was calculated counting the positive fluorescent GFP cells over the total cells. The intensity of fluorescence represented the mean of the intensity of fluorescence per labelled cell, which is correlated with gene expression and protein production [35-37].

The effect of temperature on cell transfection was studied by the incubation of HCE-2 cells at $4{ }^{\circ} \mathrm{C}$ for $30 \mathrm{~min}$, prior to the addition of the vectors. The cells were maintained for $4 \mathrm{~h}$ at $4{ }^{\circ} \mathrm{C}$, and then the cells were treated as explained above.

\subsubsection{Cellular Uptake}

The internalization of the vectors by the HCE-2 cells was studied by using vectors containing SLNs labelled with the fluorescent Nile Red dye $(\lambda=590 \mathrm{~nm})$, as previously described [8] and as explained above. The vectors were prepared $72 \mathrm{~h}$ before their addition. For this purpose, a total volume of $75 \mu \mathrm{L}$ of each vector diluted in HBS (equivalent to $2.5 \mu \mathrm{g}$ of nucleic acid) was added to each well; then, the cells were incubated for $2 \mathrm{~h}$ at $37^{\circ} \mathrm{C}$ in a $5 \% \mathrm{CO}_{2}$. Once the incubation time had finished, the culture medium was removed and the cells were detached from the plates, as described in Section 2.6.1, for the cytometry analysis of transfected cells. The entrance of the vectors was analyzed by using a CytoFLEX flow cytometer (Beckman Coulter) at $610 \mathrm{~nm}$ (ECD). For each sample, 10,000 events were collected.

Additionally, the effect of temperature on cellular uptake was studied by the incubation of cells at $4{ }^{\circ} \mathrm{C}$ for $30 \mathrm{~min}$ before the incorporation of the vectors. Once the Nile Red-labelled vectors were added to the cell cultures, the cells were maintained at $4{ }^{\circ} \mathrm{C}$ for an additional $2 \mathrm{~h}$. Finally, the cells were collected to evaluate the vector uptake by flow cytometry, as described above. In this case, the percentage of positive cells corresponds to the cells that have uptaken vectors labelled with Nile Red over the total cells.

\subsubsection{Intracellular Disposition of the Vectors}

A density of 150,000 cells in $1 \mathrm{~mL}$ per well was seeded in Millicell EZ slides (Millipore) and incubated at $37^{\circ} \mathrm{C}$ and $5 \% \mathrm{CO}_{2}$ for $24 \mathrm{~h}$. Then, they were treated with $75 \mu \mathrm{L}$ of vector equivalent to $0.8 \mu \mathrm{g}$ of CleanCap ${ }^{\mathrm{TM}}$ Cyanine 5 EGFP mRNA (5moU) as nucleic acid. After $4 \mathrm{~h}$, the slides were washed with PBS, fixed with PFA $4 \%$ and covered with the mounting fluid DAPI-fluoromount- $G^{\mathrm{TM}}$, used to label the nuclei. Then, a Leica DM IL LED Fluo inverted microscope (Leica Microsystems CMS GmbH, Wetzlar, Germany) was used to analyze the slides. 


\subsubsection{Quantification of IL-10}

To measure the levels of IL-10 expressed by the cells aft er the addition of the complexes, an Enzyme-linked Immunosorbent Assay (ELISA) kit was carried out. The secreted and intracellular IL-10 were quantified $48 \mathrm{~h}$ and $72 \mathrm{~h}$ after the addition of the mRNAand pDNA-bearing vectors encoding human IL-10, respectively. For the secreted IL-10, the medium of each well was removed and centrifuged at $12,000 \times g$ for $2 \mathrm{~min}$. For the intracellular IL-10, the cells were washed with $300 \mu \mathrm{L}$ of PBS twice, and then $400 \mu \mathrm{L}$ of reporter lysis buffer $1 \times$ was added. Finally, the plate was frozen to complete the lysis of cell culture. After thawing, each well was detached by a scrapper and the lysate was centrifuged at $12,000 \times g$ for $2 \mathrm{~min}$ at $4{ }^{\circ} \mathrm{C}$. A total of $100 \mu \mathrm{L}$ of each sample was added to a 96-well plate that was covered with the corresponding capture antibody; then the assay was performed according to the manufacturer's instructions.

\subsection{In Vivo Studies}

Five-week-old male BALB/cOlaHsd mice, with a weight ranging between 20 and $25 \mathrm{~g}$ (Envigo), were employed for the in vivo studies.

The use of the mice (license M20/2018/142) was approved by The Animal Experimentation Ethics Committee of the University of the Basque Country UPV/EHU following the Spanish and European Union (EU) laws. All the procedures were followed in accordance. The animals were accommodated under controlled temperature, humidity, and $12 \mathrm{~h}$ day-night cycles, with food and water ad libitum access.

The mice were anesthetized with 1-2\% isoflurane (IsoFlo, Abbott, Madrid, Spain) in air, at a flow rate of $0.5-1 \mathrm{~L} / \mathrm{min}$ with the aim of preventing distress during experimental manipulation.

The mice were humanely euthanatized by cervical dislocation, and then their eyes were removed. After the enucleation, the eyes were washed in a physiological saline solution, fixed with $4 \%$ PFA during $30 \mathrm{~min}$ and washed with PBS for $5 \mathrm{~min}$. Then, the eyes were immersed in $30 \%$ sucrose in PBS at $4{ }^{\circ} \mathrm{C}$ until the eyes precipitated. Then, half of the volume was removed and substituted with Tissue-Tek ${ }^{\circledR}$ O.C.T. ${ }^{\mathrm{TM}}$ and shaken at room temperature for $2 \mathrm{~h}$. Finally, the eyeballs were stored in $100 \%$ Tissue-Tek $^{\circledR}$ O.C.T. $^{\mathrm{TM}}$ to freeze at $80^{\circ} \mathrm{C}$ for future studies.

\subsubsection{Topical Administration}

The formulations described in Table 1, as well as naked mRNA encoding GFP or human IL-10, were viscosized with $1 \%$ PVA $\left(85,000-124,000 \mathrm{M}_{w}\right)$, and administered to the mice by eye drop instillation. The administration of the nanosystems was carried out in 2 doses over 3 days. In each dose, 3 instillations of $2.5 \mu \mathrm{L}$ at $3 \mathrm{~min}$ intervals were carried out, administering a final dose of $4.5 \mu \mathrm{g}$ of nucleic acid per day.

\subsubsection{Evaluation of Gene Expression}

The mice were sacrificed $24 \mathrm{~h}$ or $48 \mathrm{~h}$ after the last dose depending on the formulation administered. For GFP expression studies, the mice were sacrificed at $48 \mathrm{~h}$, except in the case of mRNA-HA-SLN $\mathrm{EE}_{\mathrm{E}}$ formulation, where the mice were sacrificed both at $24 \mathrm{~h}$ and $48 \mathrm{~h}$. For IL-10 expression studies, the mice were sacrificed at $24 \mathrm{~h}$. Then, the eyeballs were extracted, fixed and histologically evaluated by sections of $14 \mu \mathrm{m}$ on a cryostat (Cryocut 3000, Leica, Bensheim, Germany).

In order to evaluate the gene expression, two different transfection studies were carried out. In the first one, vectors contained the nucleic acid that encodes GFP, whereas in the second one vectors were bearing the nucleic acid that encodes IL-10. Both transfections were evaluated qualitatively by immunofluorescence. Sections were washed with a PB buffer. The samples were blocked and permeabilized employing a solution of $20 \% \mathrm{~PB}$, $0.3 \%$ Triton $\mathrm{X}-100,10 \%$ goat serum, and water q.s. $100 \%$. Then, the respective primary antibody, anti-GFP or anti-IL-10, was added and incubated for $24 \mathrm{~h}$ at $4{ }^{\circ} \mathrm{C}$. Secondary antibody goat anti-rabbit IgG Alexa Fluor 488 was added in both transfection assays after 
washing for $30 \mathrm{~min}$ protected from light. Finally, after washing and drying the samples, they were mounted with DAPI-Fluoromount-G. Tissue sections were examined by a Zeiss LSM800 confocal microscope (ZEISS microscopy, Oberkochen, Germany). The overlapping of fluorescence emission spectra was avoided by sequential acquisition. Six sections for each cornea were analyzed as representations of the entire tissue.

\subsection{Data Analysis}

IBM SPSS Statistics 26 (IBM) software was used to perform the statistical analysis, and the Saphiro-Wilk test and Levene test were employed for the evaluation of homogeneity and variance, and normal distribution of samples, respectively. Student's t-test was used to compare means from two independent groups and ANOVA for multiple comparisons, followed by Bonferroni or T3 Dunnet post-hoc, depending on the results of the Levene test of homogeneity of variances. $p<0.05$ was considered statistically significant. Data are shown as mean \pm standard deviation (SD).

\section{Results}

\subsection{Size and Zeta Potential of SLNs and Vectors}

Table 2 shows the average size, polydispersity index (PDI), and $\zeta$-potential of the SLNs. The particle size ranged from 93.3 to $307.8 \mathrm{~nm}$ and PDI values were lower than 0.3. The superficial particle charge ranged from +21.1 to $+68.5 \mathrm{mV}$. Significant differences $(p<0.001)$ were observed in terms of particle size and superficial charge among all SLNs. $\mathrm{SLN}_{C}$ showed the highest particle size and the lowest superficial charge, whereas $\mathrm{SLN}_{\mathrm{HM}}$ showed the smallest size and the highest superficial charge. The Particle Size Distribution Intensity Diagram of $\mathrm{SLN}_{\mathrm{HM}}$ has been included as an example in (Supplementary Material Figure S1).

Table 2. Physical characterization of solid lipid nanoparticles (SLNs).

\begin{tabular}{cccc}
\hline SLNs & Size (nm) & PDI & $\zeta$-Potential (mV) \\
\hline SLN $_{\mathrm{EE}}$ & $198.7 \pm 2.0$ & $0.26 \pm 0.01$ & $+57.8 \pm 1.7$ \\
\hline $\mathrm{SLN}_{\mathrm{HM}}$ & $93.3 \pm 0.4$ & $0.28 \pm 0.01$ & $+68.5 \pm 0.7$ \\
\hline $\mathrm{SLN}_{\mathrm{C}}$ & $307.8 \pm 3.5$ & $0.17 \pm 0.01$ & $+21.1 \pm 0.8$
\end{tabular}

DX: dextran; HA: hyaluronic acid; SLN $_{\mathrm{EE}}$ : solid lipid nanoparticle prepared by emulsification-evaporation method. $\mathrm{SLN}_{\mathrm{HM}}$ : solid lipid nanoparticle prepared by hot-melt emulsification method. $\mathrm{SLN}_{\mathrm{C}}$ : solid lipid nanoparticle prepared by coacervation method. PDI: polydispersity index. Data are expressed as mean \pm standard deviation; $n=3$.

Table 3 shows the size, PDI, and $\zeta$-potential of the SLN-based vectors containing CleanCap ${ }^{\mathrm{TM}}$ EGFP mRNA (5moU) or IL-10 mRNA customized by TriLink BioTechnologies. All formulations were prepared with protamine (P). Moreover, an aqueous solution of polysaccharide, either dextran (DX) or hyaluronic acid (HA), was incorporated into the $S_{L N}$ and $S_{L N} N_{H M}$ vectors. Since $S_{L} N_{C}$ vectors contain DEAE-dextran in their composition, only HA was used to prepare the mRNA-HA-SLN $\mathrm{C}_{\mathrm{C}}$ vector. The particle size of vectors containing EGFP mRNA ranged from 132.3 to $348.4 \mathrm{~nm}$, PDIs were lower than 0.4, and the surface charge ranged from +9.5 to $+43.9 \mathrm{mV}$. A PDI value less than 0.4 is related to the homogeneity in the size of the particles of the sample and it demonstrates a monodisperse sample population, which is considered acceptable for drug delivery [38]. Significant differences $(p<0.001)$ in terms of size were observed in both mRNA-SLN $\mathrm{HM}_{\mathrm{HM}}$ formulations and mRNA-HA-SLN ${ }_{C}$ with respect to the rest of the formulations. Regarding the superficial charge, significant differences $(p<0.001)$ were observed between SLN $_{C}$ vectors (with the lowest superficial charge), as well as mRNA-DX-SLN $\mathrm{EE}_{\mathrm{EE}}$ (with the highest superficial charge), with respect to the rest of the formulations. Particle Size Distribution Intensity Diagram of mRNA-HA-SLN ${ }_{H M}$ bearing CleanCap ${ }^{\mathrm{TM}}$ EGFP mRNA (5moU) has been included as an example in (Supplementary Material Figure S2). 
Table 3. Physical characterization of mRNA-based vectors.

\begin{tabular}{|c|c|c|c|}
\hline & Size (nm) & PDI & $\zeta$-Potential (mV) \\
\hline \multicolumn{4}{|c|}{ CleanCap $^{\text {TM }}$ EGFP mRNA (5moU) } \\
\hline mRNA-DX-SLN ${ }_{\mathrm{EE}}$ & $241.7 \pm 4.8$ & $0.29 \pm 0.01$ & $+43.9 \pm 0.25$ \\
\hline mRNA-HA-SLN ${ }_{\mathrm{EE}}$ & $287.2 \pm 1.8$ & $0.36 \pm 0.01$ & $+37.7 \pm 0.3$ \\
\hline mRNA-DX-SLN ${ }_{\mathrm{HM}}$ & $132.3 \pm 1.9$ & $0.25 \pm 0.01$ & $+38.0 \pm 1.3$ \\
\hline mRNA-HA-SLN $\mathrm{HM}$ & $132.4 \pm 1.6$ & $0.20 \pm 0.01$ & $+32.7 \pm 0.3$ \\
\hline mRNA-SLN & $292.0 \pm 1.2$ & $0.17 \pm 0.02$ & $+9.5 \pm 0.4$ \\
\hline mRNA-HA-SLN $_{\mathrm{C}}$ & $348.4 \pm 2.9$ & $0.26 \pm 0.01$ & $+13.2 \pm 0.6$ \\
\hline \multicolumn{4}{|l|}{ IL-10 mRNA } \\
\hline mRNA-DX-SLN ${ }_{\mathrm{EE}}$ & $180.1 \pm 1.1$ & $0.21 \pm 0.00$ & $+49.2 \pm 0.3$ \\
\hline mRNA-HA-SLN ${ }_{\mathrm{EE}}$ & $199.4 \pm 0.7$ & $0.21 \pm 0.00$ & $+46.3 \pm 0.1$ \\
\hline mRNA-DX-SLN ${ }_{\mathrm{HM}}$ & $116.9 \pm 0.9$ & $0.25 \pm 0.00$ & $+42.1 \pm 2.0$ \\
\hline mRNA-HA-SLN ${ }_{\mathrm{HM}}$ & $121.3 \pm 1.0$ & $0.24 \pm 0.00$ & $+41.7 \pm 0.2$ \\
\hline mRNA-SLN ${ }_{C}$ & $242.8 \pm 1.7$ & $0.25 \pm 0.01$ & $+19.4 \pm 0.9$ \\
\hline mRNA-HA-SLN ${ }_{C}$ & $283.9 \pm 4.6$ & $0.26 \pm 0.02$ & $+19.5 \pm 1.6$ \\
\hline
\end{tabular}

DX: dextran; HA: hyaluronic acid; SLN $_{\mathrm{EE}}$ : solid lipid nanoparticle prepared by emulsification-evaporation method. SLN $\mathrm{HM}_{\mathrm{H}}$ solid lipid nanoparticle prepared by hot-melt emulsification method. SLN ${ }_{C}$ : solid lipid nanoparticle prepared by coacervation method. PDI: polydispersity index. Data are expressed as mean \pm standard deviation; $n=3$.

IL-10 mRNA vectors showed a smaller particle size than those prepared with GFP mRNA, ranging from 116.9 to $283.9 \mathrm{~nm}$, with a PDI lower than 0.3 and a superficial charge from +19.4 to $+49.2 \mathrm{mV}$. Significant differences $(p<0.001)$ were observed between the vectors prepared with different SLNs with respect to the rest of the formulations in terms of particle size. Regarding the superficial charge, significant differences $(p<0.001)$ were observed between mRNA-SLN ${ }_{C}$ and mRNA-HA-SLN ${ }_{C}$ with respect to the others.

Table 4 shows the size, PDI, and $\zeta$-potential of the SLN-based vectors containing either plasmid pcDNA3-EGFP or plasmid pUNO1-hIL10. Only $\mathrm{SLN}_{\mathrm{HM}}$ were employed. All formulations were prepared with P, DX or HA, and SLNs. The particle size of the vectors bearing pcDNA3-EGFP plasmid ranged from 94.5 to $204.0 \mathrm{~nm}$, PDIs were lower than 0.3 , and the surface charge ranged from +26.3 to $+43.9 \mathrm{mV}$. Significant differences $(p<0.001)$ were noticed with regard to particle size and $\zeta$-potential between formulations. In the case of pUNO1-hIL10 vectors, the particle size ranged from 101.1 to $193.7 \mathrm{~nm}$, PDIs were less than 0.3 except for pDNA-HA-SLN $\mathrm{HM}_{\mathrm{H}}$, which was 0.48 . The superficial charge ranged from +41.4 to $+44.7 \mathrm{mV}$. Significant differences $(p<0.001)$ were reported in terms of size between formulations.

Table 4. Physical characterization of pDNA-based vectors.

\begin{tabular}{cccr}
\hline & Size (nm) & PDI & $\zeta$-Potential (mV) \\
\hline Plasmid pcDNA3-EGFP & & & $+43.9 \pm 1.01$ \\
\hline pDNA-DX-SLN & & $0.27 \pm 0.00$ & $+26.3 \pm 0.1$ \\
\hline pDNA-HA-SLN & & \\
\hline Plasmid pUNO1-hIL10 & $94.5 \pm 1.0$ & $0.25 \pm 0.01$ & $+44.7 \pm 0.6$ \\
\hline pDNA-DX-SLN & & $0.27 \pm 0.00$ & $+41.4 \pm 0.2$ \\
\hline pDNA-HA-SLN & & $0.48 \pm 0.01$ & +2.8 \\
\hline
\end{tabular}

DX: dextran; HA: hyaluronic acid; SLN $\mathrm{EE}_{\mathrm{EE}}$ : solid lipid nanoparticle prepared by emulsification-evaporation method. SLN $\mathrm{HM}_{\mathrm{H}}$ solid lipid nanoparticle prepared by hot-melt emulsification method. $\mathrm{SLN}_{\mathrm{C}}$ : solid lipid nanoparticle prepared by coacervation method. PDI: polydispersity index. Data are expressed as mean \pm standard deviation; $n=3$. 
No significant differences in particle size, PDI, or $\zeta$-potential was observed when SLNs were labelled with Nile Red (data not shown).

\subsection{Agarose Gel Electrophoresis Assay}

Figure 1 shows the ability of SLN $\mathrm{HM}_{\mathrm{HM}}$ and $\mathrm{SLN}_{\mathrm{C}}$ vectors to bind, protect, and release mRNA (Figure 1A) and the capacity of $\mathrm{SLN}_{\mathrm{HM}}$ vectors to bind, protect, and release pDNA (Figure 1B).
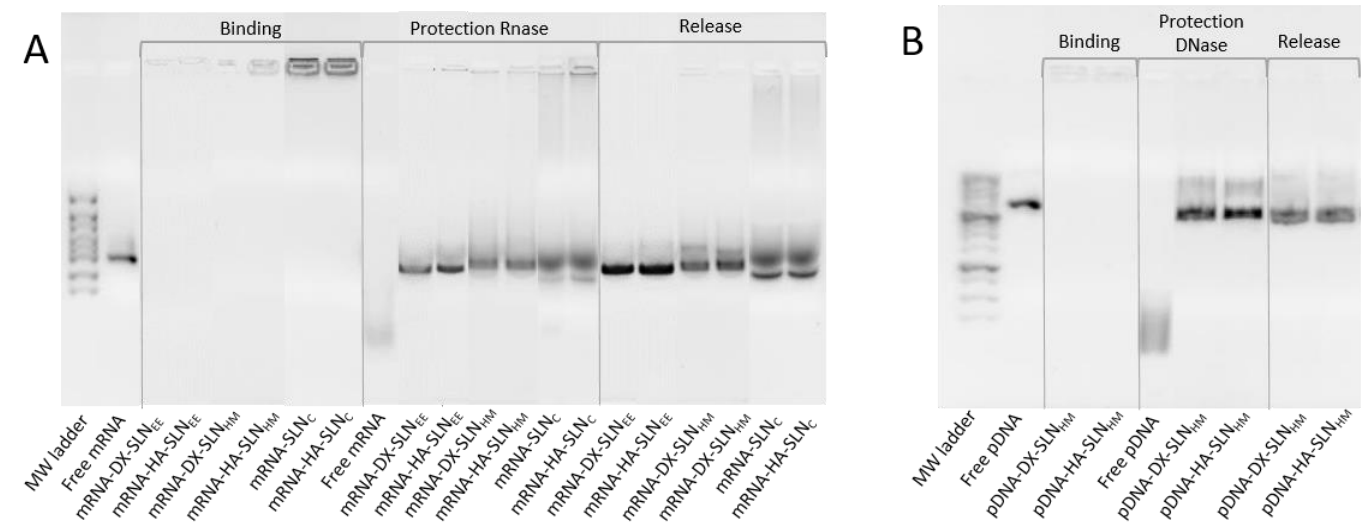

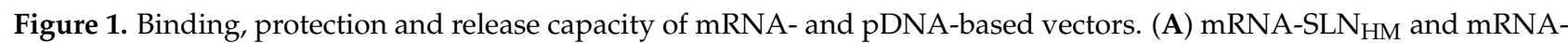
$\mathrm{SLN}_{\mathrm{C}}$; (B) pDNA-SLN $\mathrm{HM}$. DX: dextran; HA: hyaluronic acid; $\mathrm{SLN}_{\mathrm{EE}}$ : solid lipid nanoparticle prepared by emulsificationevaporation method. $\mathrm{SLN}_{\mathrm{HM}}$ : solid lipid nanoparticle prepared by hot-melt emulsification method. SLN $\mathrm{S}_{\mathrm{C}}$ : solid lipid nanoparticle prepared by coacervation method.

Regarding the binding capacity, the absence of bands in both gels and the presence of mRNA (Figure 1A) and pDNA (Figure 1B) on the loading wells indicate that nucleic acid was completely bound to the vector and unable to migrate through the gel.

Differences in the protection capacity were observed according to the formulation. Bands in the lanes corresponding to vectors prepared with $\mathrm{SLN}_{\mathrm{EE}}$ and $S \mathrm{LN}_{\mathrm{HM}}$ were more intense and less faded than those prepared with $\mathrm{SLN}_{\mathrm{C}}$; these data indicate a higher protection degree of the nucleic acid. Moreover, the presence of the two bands in the $\mathrm{SLN}_{\mathrm{C}}$ lanes indicates a lower capacity of protection.

In the case of pDNA vectors, both formulations were capable of protecting the nucleic acid against DNase I digestion. All formulations were able to release pDNA after the treatment with SDS.

\section{3. $\mathrm{pH}$ Measurement}

Table 5 shows the $\mathrm{pH}$ values of mRNA- and pDNA-based vectors formulated as eye drops (1\% PVA in HBS (Hanks' Balanced Salt solution) $\mathrm{pH}=7.4)$. The $\mathrm{pH}$ values ranged from 7.13 to 7.44 and did not show significant differences depending on the formulations.

Table 5. $\mathrm{pH}$ measurements of mRNA- and pDNA-based vectors.

\begin{tabular}{cc}
\hline Sample & pH \\
\hline mRNA-DX-SLN $_{\mathrm{EE}}$ & $7.31 \pm 0.04$ \\
mRNA-HA-SLN $_{\mathrm{EE}}$ & $7.20 \pm 0.16$ \\
mRNA-DX-SLN $_{\mathrm{HM}}$ & $7.31 \pm 0.04$ \\
mRNA-HA-SLN $_{\mathrm{HM}}$ & $7.44 \pm 0.21$ \\
mRNA-SLN $_{\mathrm{C}}$ & $7.08 \pm 0.29$ \\
mRNA-HA-SLN $_{\mathrm{C}}$ & $7.13 \pm 0.11$ \\
pDNA-DX-SLN $_{\mathrm{HM}}$ & $7.39 \pm 0.06$ \\
pDNA-HA-SLN $_{\mathrm{HM}}$ & $7.53 \pm 0.02$ \\
\hline
\end{tabular}




\subsection{Cell Culture Studies}

\subsubsection{Transfection Efficacy and Cell Viability}

Figure 2 shows the percentage of transfection and intensity of fluorescence of HCE-2 cells treated with the vectors containing mRNA GFP or pDNA at $37^{\circ} \mathrm{C}$ and $4{ }^{\circ} \mathrm{C}$.

A
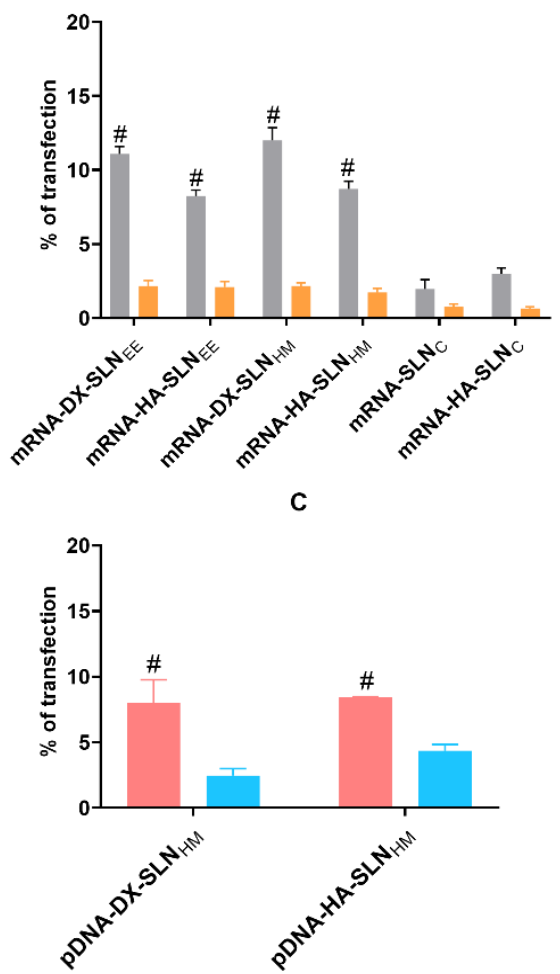

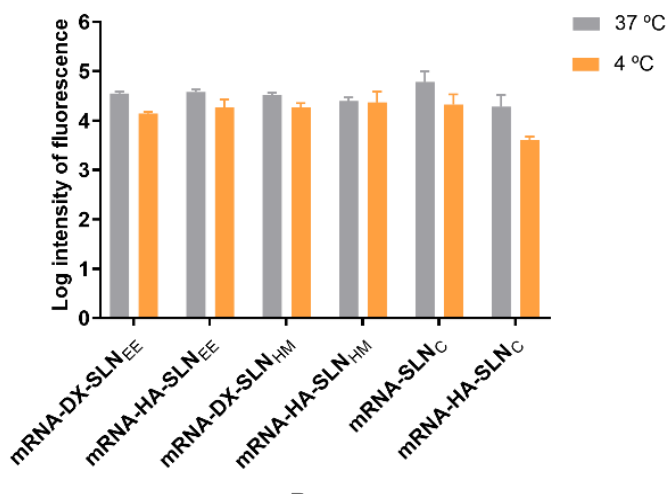

D

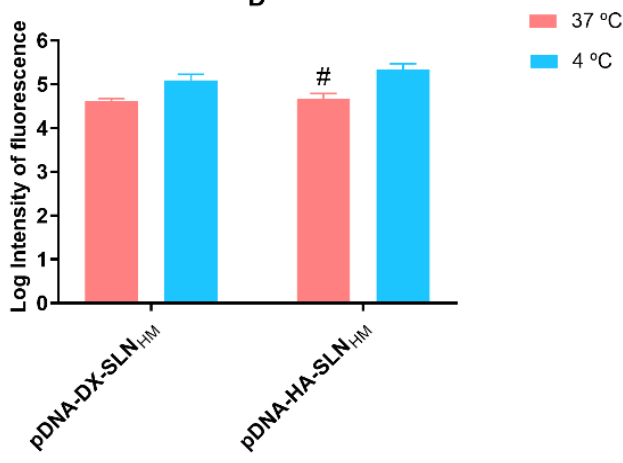

Figure 2. Flow cytometry analysis of transfection efficacy and intensity of fluorescence of HCE-2 cells after the addition of $\mathrm{SLN}_{\mathrm{EE}}, \mathrm{SLN}_{\mathrm{HM}}$ and $\mathrm{SLN}_{\mathrm{C}}$ vectors at $37^{\circ} \mathrm{C}$ and $4{ }^{\circ} \mathrm{C}$. Percentage of transfection values correspond to the positive fluorescent GFP cells over the total cells. Log of intensity of fluorescence indicates the average intensity of fluorescence per labeled cell. Data are expressed as mean \pm standard deviation; $n=3$. (A) Percentage of transfected HCE-2 cells at $37^{\circ} \mathrm{C}$ and $4{ }^{\circ} \mathrm{C} 48 \mathrm{~h}$ after administration of mRNA-based vectors. (B) Log of intensity of fluorescence of transfected HCE2 cells $48 \mathrm{~h}$ after administration of mRNA-based vectors. (C) Percentage of transfected HCE-2 cells at $37^{\circ} \mathrm{C}$ and $4{ }^{\circ} \mathrm{C} 72 \mathrm{~h}$ after administration of pDNA-based vectors. (D) Log of intensity of fluorescence of transfected HCE-2 cells $72 \mathrm{~h}$ after administration of pDNA-based vectors. \# $p<0.05$ with respect to the same vector at $4{ }^{\circ} \mathrm{C}$. DX: dextran; HA: hyaluronic acid; $\mathrm{SLN}_{\mathrm{EE}}$ : solid lipid nanoparticle prepared by emulsification-evaporation method. $\mathrm{SLN}_{\mathrm{HM}}$ : solid lipid nanoparticle prepared by hot-melt emulsification method. SLN $\mathrm{C}_{\mathrm{C}}$ solid lipid nanoparticle prepared by coacervation method.

Amongst the mRNA-based formulations at $37^{\circ} \mathrm{C}$, the transfection percentage was higher with the vectors prepared with $\mathrm{SLN}_{\mathrm{EE}}$ and $\mathrm{SLN}_{\mathrm{HM}}$ (Figure $2 \mathrm{~A}$ ) than with the vectors prepared with $\mathrm{SLN}_{\mathrm{C}}$. No significant differences were found between nanocarriers prepared with SLN $N_{\mathrm{EE}}$ and SLN $\mathrm{HM}_{\mathrm{HM}}$. With respect to the influence of temperature, the percentage of transfection decreased significantly at $4{ }^{\circ} \mathrm{C}$ in all cases. Conversely, the fluorescent intensity (Figure 2B) was similar regardless of the vectors employed and the operating temperature.

In the case of pDNA-based vectors, the percentage of transfected cells was similar with the two formulations, approximately $8 \%$. At $4{ }^{\circ} \mathrm{C}$, the transfection efficacy was lower, although the intensity of the fluorescence of pDNA-HA-SLN $\mathrm{HM}_{\mathrm{M}}$ increased significantly.

Cell viability at $37^{\circ} \mathrm{C}$ was approximately $98 \%$ for $\mathrm{SLN}_{\mathrm{EE}}$ and $\mathrm{SLN}_{\mathrm{HM}}$, and $90 \%$ for $\mathrm{SLN}_{\mathrm{C}}$. At $4{ }^{\circ} \mathrm{C}$, cell viability was approximately $98 \%$ for all formulations. 


\subsubsection{Cellular Uptake}

Figure 3 shows the efficacy of cellular uptake in HCE- 2 cells at $37^{\circ} \mathrm{C}$ and $4{ }^{\circ} \mathrm{C}$ after the addition of mRNA- and pDNA-based vectors labelled with Nile Red. Cell internalization was measured $2 \mathrm{~h}$ after the addition of the vectors to the cells cultures.

A

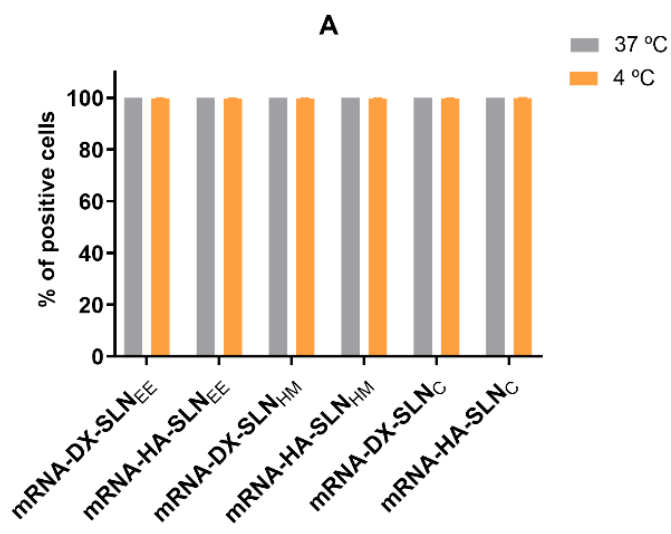

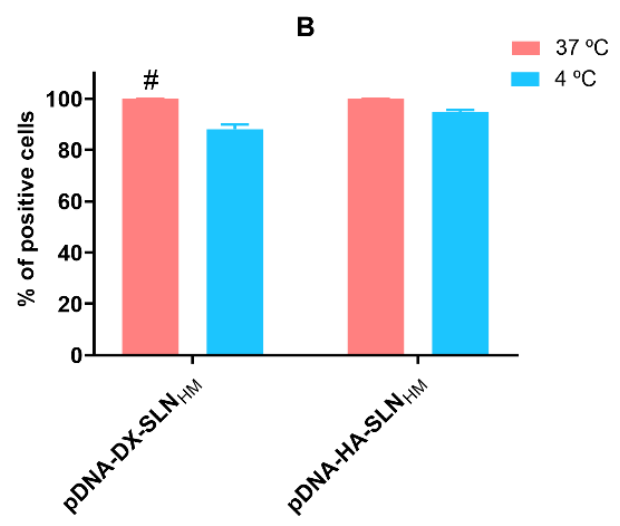

Figure 3. Cellular uptake of vectors using Nile-Red labelled SLNs in HCE-2 cells at $37{ }^{\circ} \mathrm{C}$ and $4{ }^{\circ} \mathrm{C}$ analyzed by flow cytometry. Percentage of positive cells correspond to the cells which have uptaken the vectors labeled with Nile Red over the total cells. Data are expressed as mean \pm standard deviation; $n=3$. (A) Percentage of Nile Red positive HCE- 2 cells $2 \mathrm{~h}$ after the addition of mRNA-based vectors. (B) Percentage of Nile Red positive HCE-2 cells $2 \mathrm{~h}$ after the addition of pDNA-based vectors. \# $p<0.05$ with respect to the same vector at $4{ }^{\circ} \mathrm{C}$. DX: dextran; HA: hyaluronic acid; SLN $\mathrm{EE}_{\text {: solid }}$ lipid nanoparticle prepared by emulsification-evaporation method. SLN $\mathrm{HM}_{\mathrm{M}}$ : solid lipid nanoparticle prepared by hot-melt emulsification method. SLN ${ }_{C}$ : solid lipid nanoparticle prepared by coacervation method.

In the case of mRNA-based vectors, the percentage of positive cells (Figure 3A) was over $99 \%$ at both temperatures. In the case of pDNA vectors, the percentage of positive cells was over $99 \%$ at $37{ }^{\circ} \mathrm{C}$. In contrast, the percentage of positive cells at $4{ }^{\circ} \mathrm{C}$ decreased to $88 \%$ for $\mathrm{pDNA}-\mathrm{DX}-\mathrm{SLN} \mathrm{HM}_{\mathrm{HM}}$.

\subsubsection{Intracellular Disposition of the Vectors}

Figure 4 shows the intracellular disposition of mRNA and pDNA in HCE-2 cells, represented by the red fluorescence signal. Depending on the formulation, a difference in the disposition of nucleic acid was observed.

The mRNA appeared dispersed along the cytoplasm when formulated in DX-SLN $\mathrm{EE}_{\mathrm{E}}$ and HA-SLN $\mathrm{H}_{\mathrm{H}}$ (Figure $4 \mathrm{~A}$ ). However, in the case of the remaining vectors, it appears as dots, indicating that it is more condensed.

The pDNA in the cells treated with the vectors appeared highly condensed and near the nucleus (Figure 4B); no difference in the disposition of the pDNA was observed between the two nanocarriers.

\subsubsection{Quantification of IL-10}

Figure 5 shows the levels of secreted and intracellular IL-10 in HCE-2 cells $48 \mathrm{~h}$ and $72 \mathrm{~h}$ after the addition of mRNA- and pDNA-based vectors, respectively. The mRNAvectors induced greater secretion of IL-10 than did the pDNA-based vectors. The basal production of non-treated cells was not detectable. In the case of the mRNA-based vectors, SLN $\mathrm{EE}_{\mathrm{E}}$ formulations were the most effective, while $\mathrm{SLN}_{\mathrm{C}}$ vectors showed the lowest secreted IL-10 levels.

Intracellular levels of the cytokine were close to $10 \mathrm{pg} / \mathrm{mL}$ with all formulations except pDNA-HA-SLN ${ }_{\mathrm{HM}}$, reaching 30 pg/mL (Supplementary Material Figure S3). 

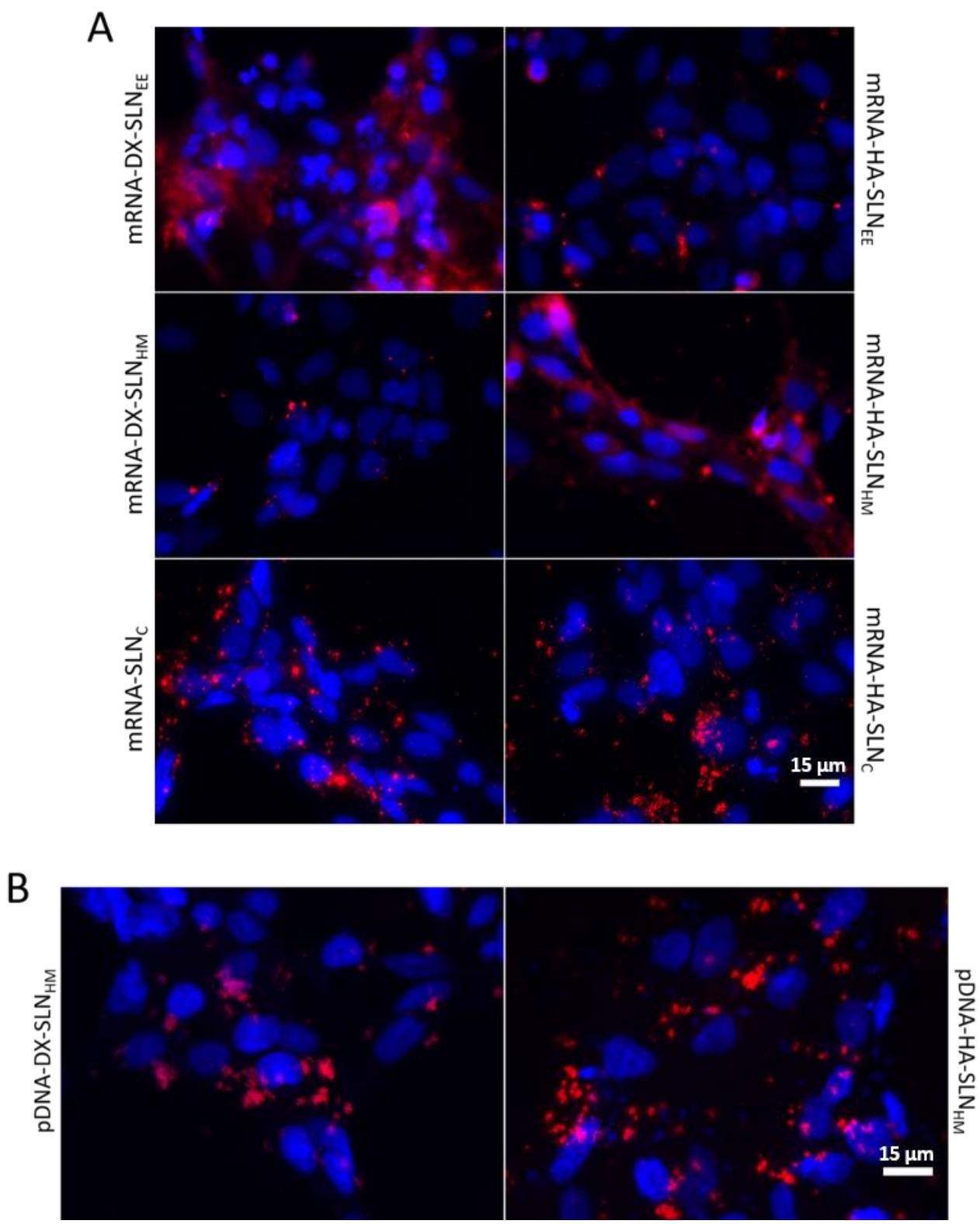

Figure 4. Confocal microscopy analysis of intracellular disposition of mRNA- and pDNA-based vectors $4 \mathrm{~h}$ after their addition in HCE-2 cells. (A) CleanCap ${ }^{\mathrm{TM}}$ Cyanine 5 EGFP mRNA (5moU) vectors formulated with P, DX and HA. (B) pcDNA3-EGFP plasmid labeled with Label IT ${ }^{\circledR} \mathrm{Cy}^{\circledR} 5$ vectors. Blue: nuclei labeled with DAPI. Red: fluorescence signal of nucleic acid labeled with $\mathrm{Cy}^{\circledR} 5$. Magnification $60 \times$. Scale bar: $15 \mu \mathrm{m}$. DX: dextran; HA: hyaluronic acid; SLN $\mathrm{EE}_{\mathrm{E}}$ : solid lipid nanoparticle prepared by emulsification-evaporation method. $\mathrm{SLN}_{\mathrm{HM}}$ : solid lipid nanoparticle prepared by hot-melt emulsification method. $\mathrm{SLN}_{\mathrm{C}}$ : solid lipid nanoparticle prepared by coacervation method. 
A

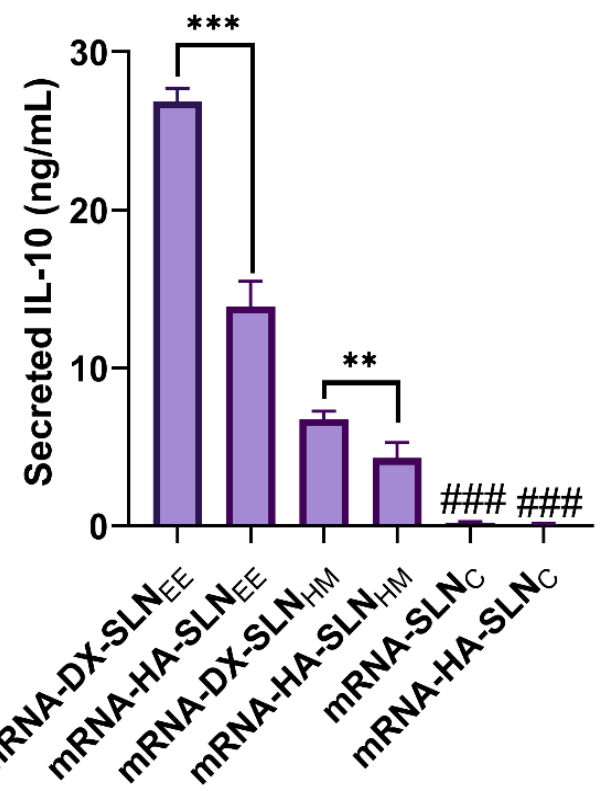

B

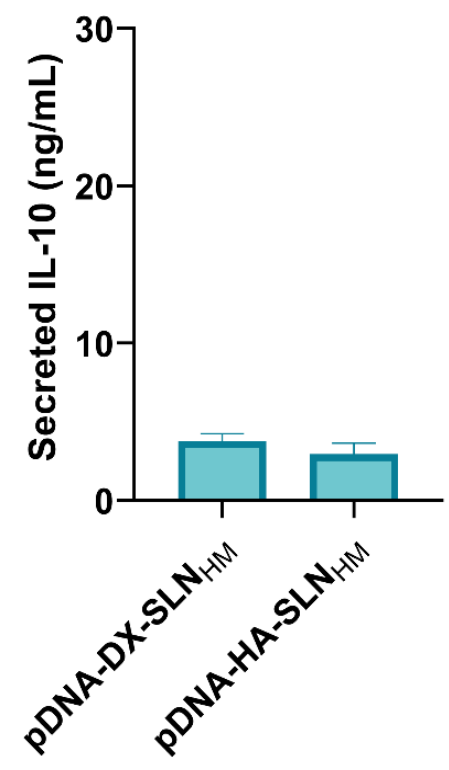

Figure 5. Levels of secreted IL-10 by HCE-2 cells after the administration of SLN-based vectors bearing IL-10 mRNA and pUNO1-hIL10 plasmid. (A) Concentration of secreted IL-10 $48 \mathrm{~h}$ after the administration of mRNA-based vectors. (B) Concentration of secreted IL-10 $72 \mathrm{~h}$ after the administration of pDNA-based vectors. \#\#\# $p<0.001$ with respect to the $\mathrm{mRNA}_{\mathrm{SLN}} \mathrm{EE}$ and mRNA$\mathrm{SLN}_{C}$ formulations. ${ }^{* *} p<0.01$ with respect to the other formulation. ${ }^{* *} p<0.001$ with respect to the other formulation. DX: dextran; HA: hyaluronic acid; $\mathrm{SLN}_{\mathrm{EE}}$ : solid lipid nanoparticle prepared by emulsification-evaporation method. $\mathrm{SLN}_{\mathrm{HM}}$ : solid lipid nanoparticle prepared by hot-melt emulsification method. SLN $_{C}$ : solid lipid nanoparticle prepared by coacervation method.

\subsection{In Vivo Studies}

\subsubsection{In Vivo Transfection with mRNA and pDNA Encoding GFP}

Vectors bearing CleanCap ${ }^{\mathrm{TM}}$ EGFP mRNA (5moU) or plasmid pcDNA3-EGFP combined with PVA were topically administered as eye drops to mice in order to assess the capacity of transfection in the corneal epithelium. Figure 6 shows representative images of the corneas $48 \mathrm{~h}$ after being transfected with the different vectors. A $48 \mathrm{~h}$ time interval between administration of the formulations and animal sacrifice was initially used, in order to compare the effects of fast acting mRNA and slow acting pDNA vectors.

GFP was detected in $100 \%$ of the sections analyzed. All formulations were able to transfect and produce GFP in the corneal epithelium. GFP produced by naked mRNA was difficult to observe, whereas the intensity of fluorescence of GFP was higher when mRNA was formulated in the vectors.

GFP produced by mRNA-DX-SLN $N_{\mathrm{EE}}$ and mRNA-DX-SLN $\mathrm{HM}_{\mathrm{H}}$ was localized continuously along the epithelium surface. In the case of mRNA-HA-SLN $\mathrm{EE}_{\mathrm{E}}$, mRNA-HA-SLN $\mathrm{HM}$, and mRNA-SLN ${ }_{C}$, uninterrupted segments of GFP were observed. In contrast, GFP in the corneas transfected with mRNA-HA-SLN ${ }_{C}$ was localized discontinuously.

Regarding transfection of the corneas with the nanocarriers prepared with pDNA, GFP was detected in a wider area with pDNA-HA-SLN ${ }_{\mathrm{HM}}$ than with pDNA-DX- SLN $\mathrm{HM}_{\text {. }}$. pDNA-based formulations were used as controls for the mRNA-based ones; naked pDNA (GFP and IL-10) was previously evaluated [32]. 


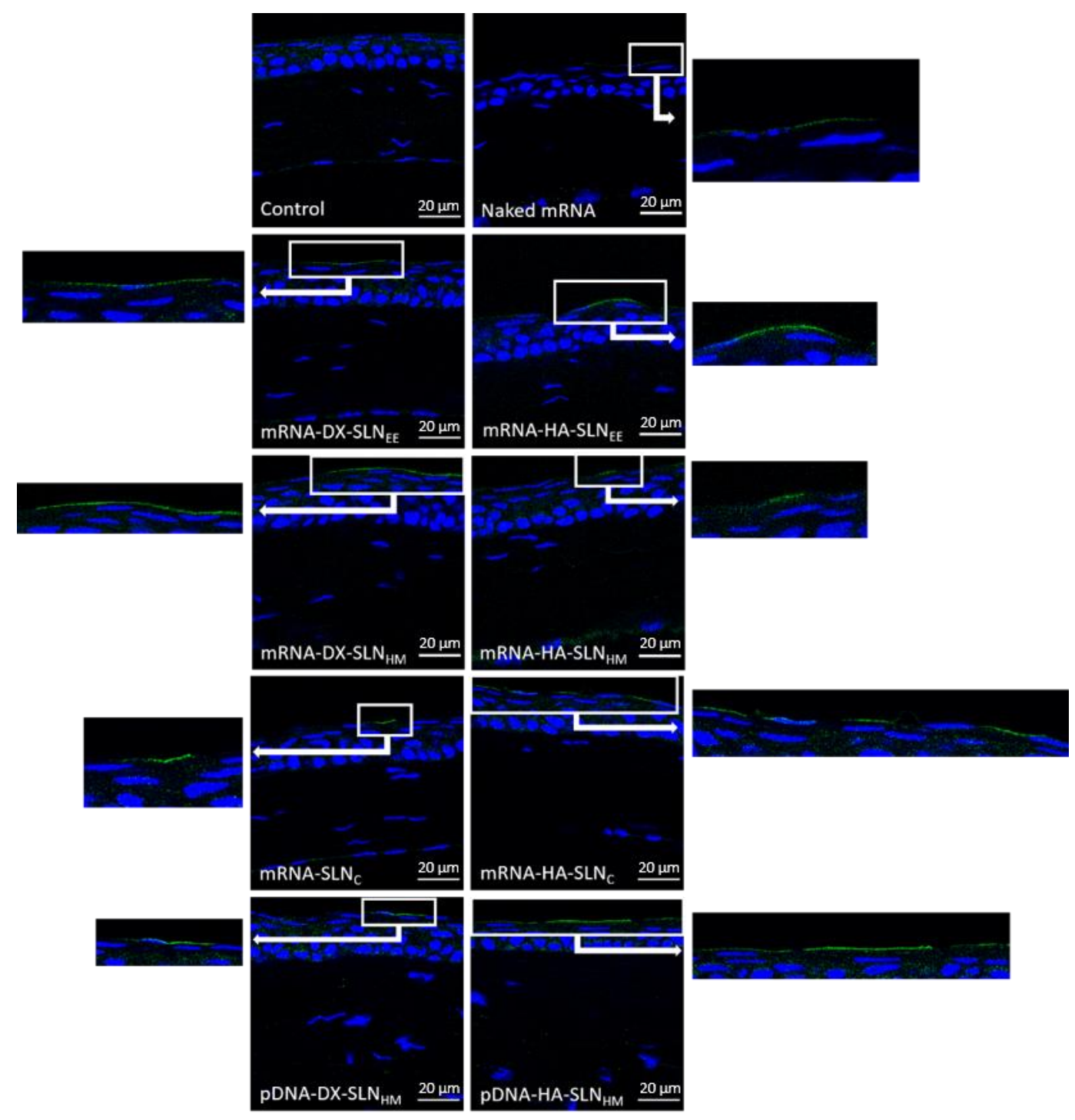

Figure 6. In vivo corneal transfection in mice $48 \mathrm{~h}$ after the administration of mRNA- and pDNA-vectors encoding GFP with the viscosifier PVA $(63 \times)$. Blue: nuclei stained with DAPI. Green: GFP detected by immunofluorescence with the secondary

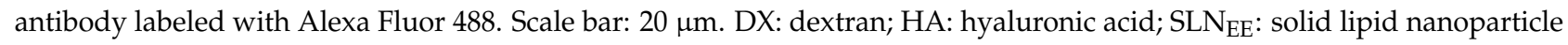
prepared by emulsification-evaporation method. $\mathrm{SLN}_{\mathrm{HM}}$ : solid lipid nanoparticle prepared by hot-melt emulsification

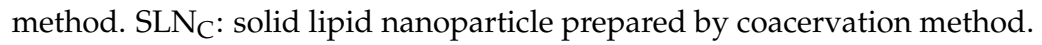

Furthermore, by analyzing the corneas of the mice treated with selected formulations (mRNA-HA-SLN $\mathrm{EE}_{\mathrm{EE}}$ ) after $24 \mathrm{~h}$, it was observed that GFP was detected in a larger surface area and with a higher intensity of fluorescence than after $48 \mathrm{~h}$ (Supplementary Material Figure S4). Considering these promising results with mRNA-based vectors, indicating a faster onset of action than initially expected, the corneas treated with the vectors bearing mRNA-IL-10 were evaluated at $24 \mathrm{~h}$ post administration. Indeed, a $24 \mathrm{~h}$ timeframe, which is required because a quick expression of IL-10 would help to deal with the progression of the inflammatory disease, would be too short for pDNA expression.

\subsubsection{In Vivo Transfection with mRNA Encoding Human IL-10}

mRNA vectors encoding IL-10 viscosized with PVA were administered to mice as eye drops. The transfection efficacy of vectors was analyzed qualitatively $24 \mathrm{~h}$ after the last administration (Figure 7). 


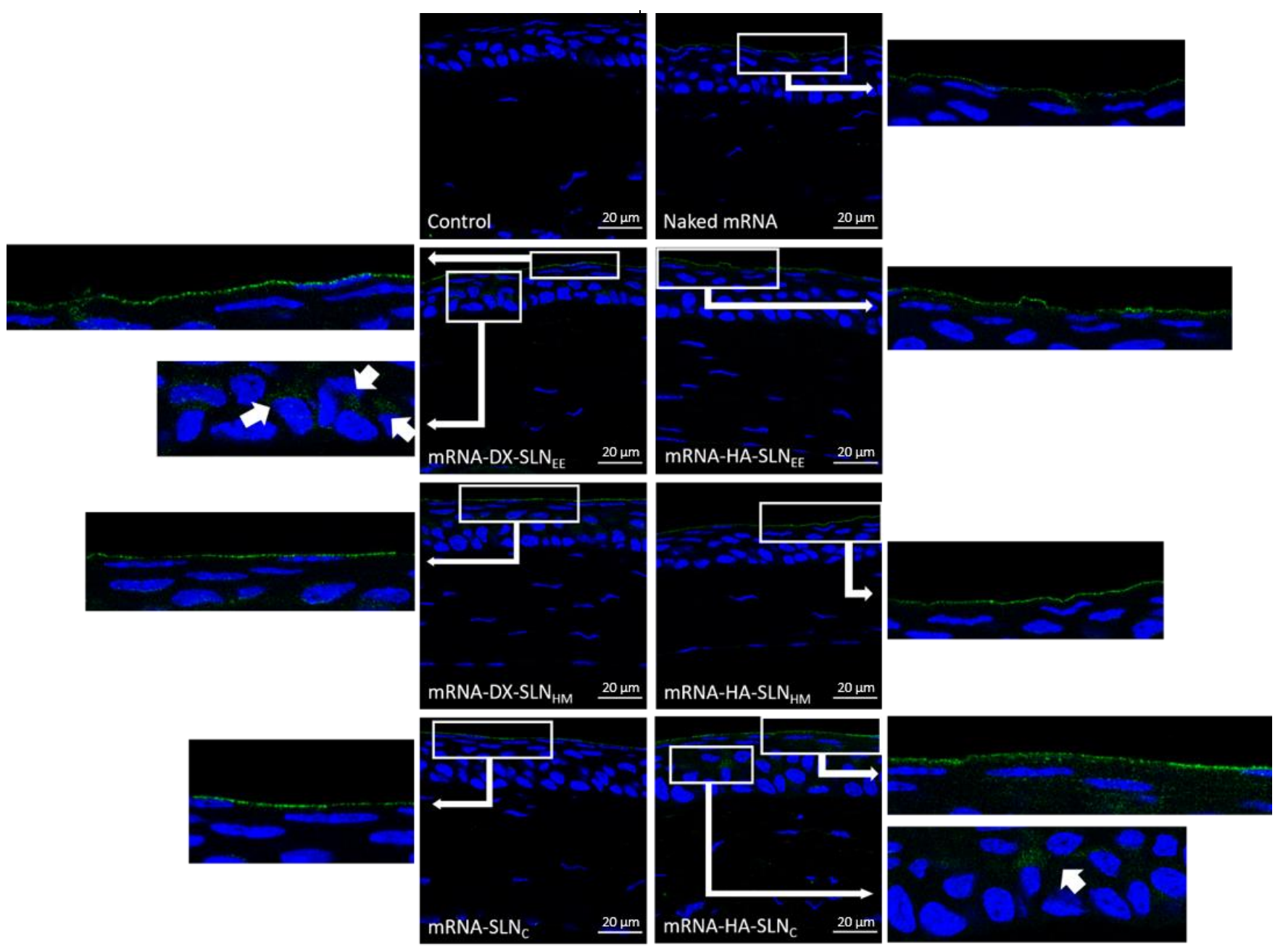

Figure 7. In vivo corneal transfection in mice $24 \mathrm{~h}$ after the administration of mRNA-vectors encoding human IL-10 with the viscosifier PVA $(63 \times)$. Blue: nuclei stained with DAPI. Green:IL-10 detected by immunofluorescence with the secondary antibody labeled with Alexa Fluor 488. Scale bar: $20 \mu \mathrm{m}$. DX: dextran; HA: hyaluronic acid; $\mathrm{SLN}_{\mathrm{EE}}$ : solid lipid nanoparticle prepared by emulsification-evaporation method. $\mathrm{SLN}_{\mathrm{HM}}$ : solid lipid nanoparticle prepared by hot-melt emulsification method. SLN ${ }_{C}$ : solid lipid nanoparticle prepared by coacervation method.

IL-10 was observed continuously along the corneal epithelium in all analyzed sections. The intensity of the fluorescence signal was higher when the corneas were treated with the nanosystems than in the case of the naked mRNA. Slight differences were found among

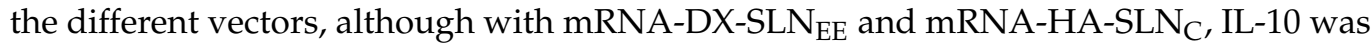
also detected in deeper corneal layers underlying the epithelium (arrows in magnification).

\section{Discussion}

The development of new nanomedicine products for mRNA-based therapies has emerged as an attractive and promising tool in the field of advanced therapies. In this study, we have developed nanovectors based on SLNs for nucleic acid delivery. Three different

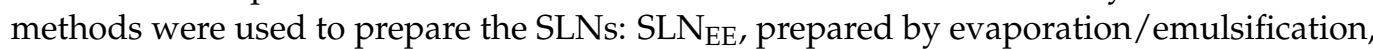
$\mathrm{SLN}_{\mathrm{HM}}$ obtained by hot-melt emulsification, and $\mathrm{SLN}_{\mathrm{C}}$ prepared by coacervation.

The preparation method influenced the physicochemical features of the SLNs, in terms of particle size and surface charge. In particular, $S L N_{\mathrm{EE}}$ and $S L N_{\mathrm{HM}}$, made up with the same chemical components but prepared by different methods, varied in particle size. Indeed, it ranged from $90 \mathrm{~nm}$ in the case of the hot emulsification procedure, which avoids the use of organic solvents, but involves a high operating temperature, to $200 \mathrm{~nm}$ in the case of the evaporation/solvent method. The solvent-free coacervation method, which 
exploits different compositions compared to the previously mentioned techniques, led to the highest particle size.

The final vectors were made up by electrostatic interactions among SLN, nucleic acid (mRNA or pDNA), and different ligands. Differences regarding the physicochemical characteristics of the SLN may lead to variations in the arrangement of the remaining components, since they are adsorbed on the SLN's surface to form the final vector. Therefore, the transfection capacity can be influenced. Firstly, the genetic material was condensed with $\mathrm{P}$, which contributes to binding and protecting the nucleic acid extra and intracellularly due to its cationic character $[39,40]$. Secondly, if required, HA or DX were added; these polysaccharides influence the interactions with the target cells and the intracellular disposition of the nucleic acid [41-43]. An additional advantage of the inclusion of one of these polysaccharides is long-term stability for mRNA-SLN-based formulations [33].

For corneal transfection, small-sized particles between 10 and $1000 \mathrm{~nm}$ reduce eye irritability after topical administrations. Moreover, they show mucoadhesive properties, which help to prolong the residence time and, consequently, to increase the drug bioavailability in the ocular tissues $[29,44]$. The vectors prepared in our work showed a mean size lower than $300 \mathrm{~nm}$ and a positive superficial charge, which facilitates cellular uptake [30] and prolongs the retention time at the corneal epithelium, thanks to the electrostatic interactions with the negatively charged ocular surface [45].

A successful transfection depends upon the balance between the protection provided by the nanosystem to the nucleic acid against degradation, and its capacity to unpack and release the same inside the cell. The preparation method and the composition of the formulations, especially the presence of different ligands, have an important influence on the mRNA condensation and consequently, on the binding, protection, and release from the vector. Electrophoresis on agarose gel (Figure 1) showed that the SLNc vectors presented a weak protection capacity against external agents, and a low release ability. In the case of mRNA-SLN $\mathrm{EE}_{\mathrm{EE}}$ and mRNA-SLN $\mathrm{HM}_{\mathrm{H}}$ vectors, differences in the condensation degree were observed (Figure 4). Nevertheless, both formulations protected and released the mRNA effectively (Figure 1). By contrast, no differences in condensation, protection, release capacity, and intracellular disposition of the genetic material were observed in pDNA vectors. Therefore, mRNA seems to be more sensitive to the formulation-related factors than does pDNA.

The interaction between the formulation components and target cells condition the internalization process, and therefore, the intracellular disposition, the endosomal escape and, consequently, the transfection capacity of the systems $[41,43,46]$. The multi-component nanosystem developed in this work could be adapted to overpass the limiting barriers at the intracellular level, providing an appropriate nucleic acid packaging in the target cells. Endocytosis is the most common mechanism used by SLNs to enter inside the cells. It is an energy- and temperature-dependent process, associated with endosomal/lysosomal pathways of cellular trafficking. Depending on the lipid composition and the physicochemical characteristics of the non-viral vector, the predominant pathway may be different [47,48]. It is well-known that all energy-dependent uptake mechanisms are inhibited by cold temperatures [49]. In the present work, the influence of temperature $\left(37^{\circ} \mathrm{C}\right.$ vs. $\left.4{ }^{\circ} \mathrm{C}\right)$ on cellular uptake and transfection efficacy was studied in the HCE-2 cells. Cellular uptake remained stable at both temperatures, which indicates that not only energy-dependent but also energy-independent entry mechanisms are undertaken. Conversely, the percentage of transfected cells decreased significantly at $4{ }^{\circ} \mathrm{C}$, whereas the intensity of fluorescence, indicative of the amount of protein produced by transfected cells, remained almost stable. Therefore, at cold temperatures the few transfected cells are able to produce a higher amount of protein. These results show that the transfection of HCE-2 cells is favoured by energy-dependent mechanisms, although the production of protein seems to be more efficient when the vectors are taken up by energy-independent mechanisms.

The transfection capacity of mRNA- and pDNA-based vectors was similar in terms of transfected cells and intensity of fluorescence (Figure 2). Contrarily to pDNA, mRNA 
bypasses one of most limiting steps: it does not need to reach the nucleus to transfect, and therefore, it is expected to lead to a faster transfection rate. Noteworthy, our results seem to indicate that the bottleneck for a successful transfection in corneal epithelial cells is before the nuclear entry; as a consequence, the intra-cytoplasmic behaviour of our nanosystems seems to be the limiting step for the transfection.

Transfection studies with the nanovectors bearing pDNA or mRNA encoding the antiinflammatory cytokine IL-10 were also carried out in HCE-2 cells. The IL-10 was measured in the culture media and at the intracellular level. The mRNA vectors most efficient in terms of IL-10 production were those containing the SLNs prepared by the solvent/evaporation method. For the same kind of SLNs $\left(\mathrm{SLN}_{\mathrm{EE}}\right.$ or $\left.\mathrm{SLN}_{\mathrm{HM}}\right)$, those containing DX were more effective than those containing HA. The mRNA-vectors, including the SLNs prepared by coacervation, hardly produced IL-10. The levels of IL-10 secreted by cells treated with the vectors prepared with $\mathrm{SLN}_{\mathrm{HM}}$ and either mRNA or pDNA were similar (Figure 5). It is expected that levels over $0.8 \mathrm{ng} / \mathrm{mL}$ of IL-10 would exert the anti-inflammatory effect [50]. In previous works, we showed that SLNs-based systems bearing pDNA were able to produce up to $10 \mathrm{ng} / \mathrm{mL}$ of IL-10 in HCE-2 cells [8]. In our case, the IL-10 levels

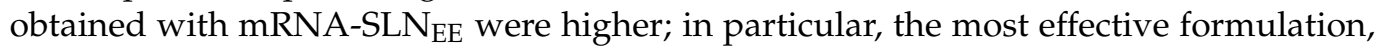
mRNA-DX-SLN ${ }_{\mathrm{EE}}$, showed IL-10 levels almost three-folds higher.

The formulation of nanodelivery systems plays a crucial role in the development of medicinal products based on gene therapy, and specifically, in ocular gene therapy. An optimal ophthalmic drug formulation should comply to an adequate bioavailability, an increased permeability, an improved stability against degradation, a prolonged retention on the eye surface, and an augmented interaction with the cornea and targeted delivery [51]. Indeed, due to the pseudoplastic properties of the tear fluid, the inclusion of thickening agents could be advantageous in order to increase the corneal retention time and ocular bioavailability [52]. For the in vivo studies, the thickening agent PVA was added to the vectors. The non-ionic and synthetic biodegradable hydrophilic polymer PVA [53] is approved by the FDA for use in ophthalmic formulations [54]. PVA has been widely used because of its muco-mimetic properties, high water retention capacity, oxygen permeability, and low toxicity [55]. These properties confer to our nanosystems the ability to increase the residence time, and consequently improve the ocular bioavailability, reducing the drainage from lachrymal fluid [56,57]. In early studies, our group showed that the combination of SLN-based vectors with PVA provided a higher retention on the cornea [32]. Ophthalmic formulations should have the $\mathrm{pH}$ of the lacrimal fluid, or a $\mathrm{pH}$ within the range of the ocular comfort range, in order to ensure a good tolerance $[58,59]$. The ocular $\mathrm{pH}$ ranges from 6.6 to 7.8 ; it is reported that a $\mathrm{pH}$ value of an ocular preparation ranged outside 5.0-8.5 causes extra lachrymation and decreases the ocular residence time [60]. Our formulations showed $\mathrm{pH}$ values within the ocular tolerance range, from 7.1 to 7.5 (Table 5).

In vivo studies in mice were first carried out to evaluate the formulations containing mRNA or pDNA for GFP expression. Since GFP, once produced, remains at the intracellular level, it allowed us to identify the corneal layers where transfection occurs, after the instillation on the mice ocular surface with these vectors. Since the cornea is a complex structure, mRNA-delivery systems are engineered to induce the therapeutic protein expression in the cornea, specifically in the stratified and renewable epithelial layer, where a high number of cells can be transfected. Another alternative could be the transfection of the innermost layer of the cornea, the endothelial layer, associated with a difficult accessibility. Indeed, this layer contains a low number of cells that do not undergo division and gene expression could be maintained for longer times. To this aim, DNA could be most advantageous, since it provides a more persistent transgene production than mRNA. However, although we have previously shown the capacity of DNA-based formulations to transfect the cornea [8], mRNA possesses several advantages that could make it a better option for corneal inflammation management. Indeed, mRNA shows a better safety profile than DNA; the encoded protein is earlier produced, and its expression is transitory, which makes the behaviour of this molecule easier to predict. Moreover, taking into account that the corneal epithelium 
only needs 7 to 14 days to achieve a complete renewal [61], a short-term expression of the protein is required.

All mRNA-based formulations included in this experimental work transfected the cornea in vivo and showed a higher intensity of fluorescence than naked mRNA. Thus, the SLNs resulted necessary to obtain a high transfection efficiency. These formulations were able to transfect only the epithelial cells but not the inner layers of the cornea, regardless of their different particle size. The intensity of fluorescence of GFP observed in the HCE-2 cells in vitro, representative of the protein production, was similar for all formulations, and it seems to correlate better with the in vivo results than with the percentage of transfected cells in vitro. Nevertheless, the lack of a strict correlation between in vitro and in vivo studies [62-65] highlights the necessity to perform the latter ones at the earliest phases of the pharmaceutical development process, in order to perform adequate selection and optimization of candidate formulations.

Finally, we evaluated the capacity of our formulations to induce the production of the anti-inflammatory cytokine IL-10 [51]. In view of the fact that IL-10 is a secreted protein, it may be produced in the epithelial corneal cells and diffuse through the cornea to reach deeper layers. Moreover, for corneal inflammation management, a quick expression of IL10 would help to deal with the progression of the disease. In this context, we administered the formulations for 3 days and, $24 \mathrm{~h}$ after the last administration, the presence of IL-10 in the cornea was assessed. When mice were treated with an mRNA-DX-SLN $\mathrm{EE}_{\mathrm{E}}$ vector, the best performing formulation in in vitro experiments in HCE-2 cells (Figure 5), the interleukin was even observed in the deeper layers of the epithelium (Figure 7). mRNAHA-SLN $\mathrm{C}_{C}$ vectors also showed a high capacity to produce IL-10, despite the low efficacy observed in vitro. It should be considered that the transfection efficacy of the nanovectors could be increased in inflamed corneas, as the histological structure of corneal layers would be altered and disorganized, resulting in a potentially increased permeation of the nanosystems into the tissue. Within this concern, in previous studies with SLN-based nanosystem containing pDNA as the nucleic acid, vectors prepared with the polysaccharide HA showed the highest transfection efficacy [32]. pDNA and mRNA differ not only in their physico-chemical characteristics, but also in terms of their intracellular barriers to overcome in order to achieve protein production. Our results confirm the necessity of the adaptation of the nanovector to the target cells and to the nature of the nucleic acid, in order to obtain an effective transfection.

\section{Conclusions}

The nature of the nucleic acid and the target cell are key points for the design and optimization of nanosystems aimed at ocular gene delivery, with mRNA being more sensitive to the formulation-related factors than pDNA. Nanomedicinal products design is based, initially, on in vitro studies. We have demonstrated that the HCE-2 cells' transfection is favoured by energy-dependent mechanisms, but the production of protein is more efficient when the vectors are taken up by energy-independent mechanisms. However, the lack of correlation observed between in vitro and in vivo assays has highlighted the necessity to perform in vivo studies at the earliest phases of the pharmaceutical development of nucleic acid delivery systems. In the present work, SLNs allowed the ability to obtain a high transfection efficiency in vivo. Therefore, topical administration to mice of eye drops containing mRNA formulated in SLNs has shown to be a feasible strategy to tackle corneal inflammation by de novo fast IL-10 production from corneal epithelial cells.

Supplementary Materials: The following are available online at https:/ / www.mdpi.com/article/10 .3390/pharmaceutics13091472/s1, Figure S1: Particle Size Distribution Intensity Diagram of SLN Figure S2: Particle Size Distribution Intensity Diagram of mRNA-HA-SLN $\mathrm{HM}_{\mathrm{M}}$ bearing CleanCap ${ }^{\mathrm{TM}}$ EGFP mRNA (5moU). Figure S3: Intracellular levels of IL-10 in HCE-2 cells after the administration of SLN-based vectors bearing IL-10 mRNA and pUNO1-hIL10 plasmid. Figure S4: In vivo corneal transfection in wild type mice $24 \mathrm{~h}$ and $48 \mathrm{~h}$ after the administration of mRNA-HA-SLN $\mathrm{EE}_{\text {with PVA }}$ $(63 \times)$. 
Author Contributions: Conceptualization, I.G.-A., A.d.P.-R. and M.Á.S.; methodology, I.G.-A., J.R.-C. and M.B.-M.; software, A.d.P.-R. and M.V.-P.; validation, A.d.P.-R. and M.Á.S.; formal analysis, I.G.-A., A.d.P.-R. and M.Á.S.; investigation, I.G.-A.; resources, A.R.-G. and A.d.P.-R.; data curation, M.Á.S.; writing-original draft preparation, I.G.-A., A.d.P.-R. and M.Á.S.; writing-review and editing, J.R.-C., M.B.-M., M.V.-P., A.R.-G., S.G. and L.B.; visualization, A.d.P.-R.; supervision, L.B., A.d.P.-R and M.Á.S.; project administration, A.R.-G. and M.Á.S.; funding acquisition, A.R.-G. and M.Á.S. All authors have read and agreed to the published version of the manuscript.

Funding: This research was funded by MCIU/AEI/FEDER, UE (SAF2014-53092-R), the UPV/EHU (GIU 20/048) and by the Università degli Studi di Torino (Ricerca Locale 2019).

Informed Consent Statement: Not applicable.

Data Availability Statement: The data presented in this study are available on request from the corresponding author.

Acknowledgments: I. Gómez-Aguado and M. Beraza-Millor thank the University of the Basque Country UPV /EHU (PIF17/067 and PIFG19/36, respectively) and J. Rodríguez-Castejón thanks the Basque Government (PRE_2020_2_0120) for their research grants.

Conflicts of Interest: The authors declare no conflict of interest.

\section{References}

1. del Pozo-Rodríguez, A.; Torrecilla, J.; Rodríguez-Gascón, A.; Solinís, M.Á. Nonviral Delivery Systems for Gene Therapy for Retina and Posterior Segment Disease BT. In Drug Delivery for the Retina and Posterior Segment Disease; Patel, J.K., Sutariya, V., Kanwar, J.R., Pathak, Y.V., Eds.; Springer International Publishing: Cham, Switzerland, 2018; pp. 131-149, ISBN 978-3-319-95807-1.

2. Trigueros, S.; Domènech, E.B.; Toulis, V.; Marfany, G. In vitro gene delivery in retinal pigment epithelium cells by plasmid dna-wrapped gold nanoparticles. Genes 2019, 10, 289. [CrossRef] [PubMed]

3. Di Iorio, E.; Barbaro, V.; Alvisi, G.; Trevisan, M.; Ferrari, S.; Masi, G.; Nespeca, P.; Ghassabian, H.; Ponzin, D.; Palù, G. New Frontiers of Corneal Gene Therapy. Hum. Gene Ther. 2019, 30, 923-945. [CrossRef] [PubMed]

4. Gene Therapy Clinical Trials Worldwide. Provided by Journal of Gene Medicine, John Wileys and Sons LTD. 2021. Available online: https:/ / a873679.fmphost.com/fmi/webd/GTCT (accessed on 31 May 2021).

5. Torrecilla, J.; del Pozo-Rodríguez, A.; Vicente-Pascual, M.; Solinís, M.Á.; Rodríguez-Gascón, A. Targeting corneal inflammation by gene therapy: Emerging strategies for keratitis. Exp. Eye Res. 2018, 176, 130-140. [CrossRef] [PubMed]

6. Beeken, L.J.; Ting, D.S.J.; Sidney, L.E. Potential of mesenchymal stem cells as topical immunomodulatory cell therapies for ocular surface inflammatory disorders. Stem Cells Transl. Med. 2021, 10, 39-49. [CrossRef]

7. Ghasemi, H.; Ghazanfari, T.; Yaraee, R.; Owlia, P.; Hassan, Z.M.; Faghihzadeh, S. Roles of IL-10 in Ocular Inflammations: A Review. Ocul. Immunol. Inflamm. 2012, 20, 406-418. [CrossRef]

8. Vicente-Pascual, M.; Albano, A.; Solinís, M.; Serpe, L.; Rodríguez-Gascón, A.; Foglietta, F.; Muntoni, E.; Torrecilla, J.; PozoRodríguez, A.D.; Battaglia, L. Gene delivery in the cornea: In vitro \& ex vivo evaluation of solid lipid nanoparticle-based vectors. Nanomedicine 2018, 13, 1847-1864. [CrossRef]

9. Gómez-Aguado, I.; Rodríguez-Castejón, J.; Vicente-Pascual, M.; Rodríguez-Gascón, A.; Solinís, M.Á.; del Pozo-Rodríguez, A. Nanomedicines to Deliver mRNA: State of the Art and Future Perspectives. Nanomaterials 2020, 10, 364. [CrossRef]

10. Damase, T.R.; Sukhovershin, R.; Boada, C.; Taraballi, F.; Pettigrew, R.I.; Cooke, J.P. The Limitless Future of RNA Therapeutics. Front. Bioeng. Biotechnol. 2021, 9, 1-24. [CrossRef]

11. Del Pozo-Rodríguez, A.; Rodríguez-Gascón, A.; Rodríguez-Castejón, J.; Vicente-Pascual, M.; Gómez-Aguado, I.; Battaglia, L.S.; Solinís, M.Á. Gene Therapy. In Advances in Biochemical Engineering/Biotechnology; Springer: Berlin/Heidelberg, Germany, 2019; Volume 171, pp. 321-368, ISBN 978-3-030-40464-2.

12. May, M. After COVID-19 successes, researchers push to develop mRNA vaccines for other diseases. Nat. Med. 2021, 27, 930-932. [CrossRef]

13. Igyártó, B.Z.; Jacobsen, S.; Ndeupen, S. Future considerations for the mRNA-lipid nanoparticle vaccine platform. Curr. Opin. Virol. 2021, 48, 65-72. [CrossRef]

14. Chakraborty, C.; Sharma, A.R.; Bhattacharya, M.; Lee, S.-S. From COVID-19 to Cancer mRNA Vaccines: Moving From Bench to Clinic in the Vaccine Landscape. Front. Immunol. 2021, 12, 1-17. [CrossRef] [PubMed]

15. U.S. Department of Health and Human Services; Food and Drug Administration. COVID-19 Vaccines. Available online: https: / / www.fda.gov/emergency-preparedness-and-response/coronavirus-disease-2019-COVID-19/COVID-19-vaccines (accessed on 22 July 2021).

16. European Medicines Agency; Science Medicines Health. COVID-19 Vaccines. Available online: https://www.ema.europa. $\mathrm{eu} / \mathrm{en} /$ human-regulatory / overview/public-health-threats / coronavirus-disease-COVID-19/treatments-vaccines /COVID-19 -vaccines (accessed on 22 July 2021). 
17. Gediz Erturk, A.; Sahin, A.; Ay, E.B.; Pelit, E.; Bagdatli, E.; Kulu, I.; Gul, M.; Mesci, S.; Eryilmaz, S.; Yildirim, T.; et al. molecules A Multidisciplinary Approach to Coronavirus Disease (COVID-19). Molecules 2021, 26, 3526. [CrossRef] [PubMed]

18. Paganelli, R.; Frasca, D.; Nisini, R.; Bajaj, V.; Gadi, N.; Spihlman, A.P.; Wu, S.C.; Choi, C.H.; Moulton, V.R. Aging, Immunity, and COVID-19: How Age Influences the Host Immune Response to Coronavirus Infections? Front. Physiol. 2020, 11, 1793. [CrossRef]

19. del Pozo-Rodríguez, A.; Solinís, M.Á.; Rodríguez-Gascón, A. Applications of lipid nanoparticles in gene therapy. Eur. J. Pharm. Biopharm. 2016, 109, 184-193. [CrossRef]

20. Wang, Y.; Rajala, A.; Rajala, R.V.S. Lipid Nanoparticles for Ocular Gene Delivery. J. Funct. Biomater. 2015, 6, 379-394. [CrossRef]

21. Barba, A.A.; Bochicchio, S.; Dalmoro, A.; Lamberti, G. Lipid delivery systems for nucleic-acid-based-drugs: From production to clinical applications. Pharmaceutics 2019, 11, 360. [CrossRef] [PubMed]

22. Mehnert, W.; Mader, K. Advances in the Cognitive Neuroscience of Neurodevelopmental Disorders: Views from Child Psychiatry and Medical Genetics. Neurodev. Disord. 2020, 47, 165-196. [CrossRef]

23. Müller, R.H.; Radtke, M.; Wissing, S.A. Solid lipid nanoparticles (SLN) and nanostructured lipid carriers (NLC) in cosmetic and dermatological preparations. Adv. Drug Deliv. Rev. 2002, 54, 131-155. [CrossRef]

24. Yadav, N.; Khatak, S.; Sara, U.S. Solid lipid nanoparticles-A review. Int. J. Appl. Pharm. 2013, 5, 8-18. [CrossRef]

25. Ramamoorth, M.; Narvekar, A. Non viral vectors in gene therapy-An overview. J. Clin. Diagn. Res. 2015, 9, GE01-GE06. [CrossRef] [PubMed]

26. Trucillo, P.; Campardelli, R. Production of solid lipid nanoparticles with a supercritical fluid assisted process. J. Supercrit. Fluids 2019, 143, 16-23. [CrossRef]

27. Chattopadhyay, P.; Shekunov, B.Y.; Yim, D.; Cipolla, D.; Boyd, B.; Farr, S. Production of solid lipid nanoparticle suspensions using supercritical fluid extraction of emulsions (SFEE) for pulmonary delivery using the AERx system. Adv. Drug Deliv. Rev. 2007, 59, 444-453. [CrossRef]

28. Singh, M.; Guzman-Aranguez, A.; Hussain, A.; Srinivas, C.S.; Kaur, I.P. Solid lipid nanoparticles for ocular delivery of isoniazid: Evaluation, proof of concept and in vivo safety \& kinetics. Nanomedicine 2019, 14, 465-491. [CrossRef] [PubMed]

29. Mobaraki, M.; Soltani, M.; Harofte, S.Z.; Zoudani, E.L.; Daliri, R.; Aghamirsalim, M.; Raahemifar, K. Biodegradable nanoparticle for cornea drug delivery: Focus review. Pharmaceutics 2020, 12, 1232. [CrossRef]

30. Battaglia, L.; Serpe, L.; Foglietta, F.; Muntoni, E.; Gallarate, M.; Del Pozo Rodriguez, A.; Solinis, M.A. Application of lipid nanoparticles to ocular drug delivery. Expert Opin. Drug Deliv. 2016, 13, 1743-1757. [CrossRef] [PubMed]

31. Bachu, R.D.; Chowdhury, P.; Al-Saedi, Z.H.F.; Karla, P.K.; Boddu, S.H.S. Ocular Drug Delivery Barriers-Role of Nanocarriers in the Treatment of Anterior Segment Ocular Diseases. Pharmaceutics 2018, 10, 28. [CrossRef]

32. Vicente-Pascual, M.; Gómez-Aguado, I.; Rodríguez-Castejón, J.; Rodríguez-Gascón, A.; Muntoni, E.; Battaglia, L.; Del PozoRodríguez, A.; Aspiazu, M.Á.S. Topical Administration of SLN-Based Gene Therapy for the Treatment of Corneal Inflammation by De Novo IL-10 Production. Pharmaceutics 2020, 12, 584. [CrossRef]

33. Gómez-Aguado, I.; Rodríguez-Castejón, J.; Vicente-Pascual, M.; Rodríguez-Gascón, A.; Del Pozo-Rodríguez, A.; Solinís Aspiazu, M.Á. Nucleic Acid Delivery by Solid Lipid Nanoparticles Containing Switchable Lipids: Plasmid DNA vs. Messenger RNA. Molecules 2020, 25, 5995. [CrossRef]

34. Sloot, Y.J.E.; Rabold, K.; Ulas, T.; De Graaf, D.M.; Heinhuis, B.; Händler, K.; Schultze, J.L.; Netea, M.G.; Smit, J.W.A.; Joosten, L.A.B.; et al. Interplay between thyroid cancer cells and macrophages: Effects on IL-32 mediated cell death and thyroid cancer cell migration. Cell. Oncol. 2019, 42, 691-703. [CrossRef] [PubMed]

35. Tsai, Y.-C.; Tsai, T.-H.; Chang, C.-P.; Chen, S.-F.; Lee, Y.-M.; Shyue, S.-K. Linear correlation between average fluorescence intensity of green fluorescent protein and the multiplicity of infection of recombinant adenovirus. J. Biomed. Sci. 2015, 22, 31. [CrossRef] [PubMed]

36. Sandhu, K.S.; Al-Rubeai, M. Monitoring of the Adenovirus Production Process by Flow Cytometry. Biotechnol. Prog. 2008, 24, 250-261. [CrossRef]

37. Xu, X.; Lambrecht, A.D.; Xiao, W. Chapter 13-Yeast Survival and Growth Assays. Methods Mol. Biol. 2014, 1163, 33-44. [CrossRef]

38. Mahareek, O.; Fahmi, A.; Abdur-Rahman, M.; Shemis, M. Synthesis, Characterization and Optimization of PCL-based Nanocapsules for Delivery of Anticancer Chemotheraputic Drug. J. Sci. Res. Sci. 2019, 36, 412-423. [CrossRef]

39. Delgado, D.; Del Pozo-Rodríguez, A.; Solinís, M.Á.; Rodríguez-Gascón, A. Understanding the mechanism of protamine in solid lipid nanoparticle-based lipofection: The importance of the entry pathway. Eur. J. Pharm. Biopharm. 2011, 79, 495-502. [CrossRef]

40. Ruseska, I.; Fresacher, K.; Petschacher, C.; Zimmer, A. Use of protamine in nanopharmaceuticals-A review. Nanomaterials 2021, 11, 1508. [CrossRef]

41. Delgado, D.; Gascón, A.R.; Del Pozo-Rodríguez, A.; Echevarría, E.; Ruiz De Garibay, A.P.; Rodríguez, J.M.; Solinís, M.Á. Dextranprotamine-solid lipid nanoparticles as a non-viral vector for gene therapy: In vitro characterization and in vivo transfection after intravenous administration to mice. Int. J. Pharm. 2012, 425, 35-43. [CrossRef] [PubMed]

42. Apaolaza, P.S.; del Pozo-Rodríguez, A.; Torrecilla, J.; Rodríguez-Gascón, A.; Rodríguez, J.M.; Friedrich, U.; Weber, B.H.F.; Solinís, M.A. Solid lipid nanoparticle-based vectors intended for the treatment of X-linked juvenile retinoschisis by gene therapy: In vivo approaches in Rs1h-deficient mouse model. J. Control. Release 2015, 217, 273-283. [CrossRef] [PubMed]

43. Apaolaza, P.S.; Delgado, D.; Del Pozo-Rodríguez, A.; Gascón, A.R.; Solinís, M.Á. A novel gene therapy vector based on hyaluronic acid and solid lipid nanoparticles for ocular diseases. Int. J. Pharm. 2014, 465, 413-426. [CrossRef]

44. Omerović, N.; Vranić, E. Application of nanoparticles in ocular drug delivery systems. Health Technol. 2020, 10, 61-78. [CrossRef] 
45. Wong, C.W.; Metselaar, J.M.; Storm, G.; Wong, T.T. A review of the clinical applications of drug delivery systems for the treatment of ocular anterior segment inflammation. Br. J. Ophthalmol. 2020, 1-6. [CrossRef]

46. Li, J.; Chen, Q.; Zha, Z.; Li, H.; Toh, K.; Dirisala, A.; Matsumoto, Y.; Osada, K.; Kataoka, K.; Ge, Z. Ternary polyplex micelles with PEG shells and intermediate barrier to complexed DNA cores for efficient systemic gene delivery. J. Control. Release 2015, 209, 77-87. [CrossRef] [PubMed]

47. Al Khafaji, A.S.; Donovan, M.D. Endocytic uptake of solid lipid nanoparticles by the nasal mucosa. Pharmaceutics 2021, 13, 761. [CrossRef] [PubMed]

48. Manzanares, D.; Ceña, V. Endocytosis: The nanoparticle and submicron nanocompounds gateway into the cell. Pharmaceutics 2020, 12, 371. [CrossRef]

49. Nagai, N.; Ogata, F.; Otake, H.; Nakazawa, Y.; Kawasaki, N. Energy-dependent endocytosis is responsible for drug transcorneal penetration following the instillation of ophthalmic formulations containing indomethacin nanoparticles. Int. J. Nanomedicine 2019, 14, 1213-1227. [CrossRef] [PubMed]

50. Wang, X.; Coradin, T.; Hélary, C. Modulating inflammation in a cutaneous chronic wound model by IL-10 released from collagen-silica nanocomposites: Via gene delivery. Biomater. Sci. 2018, 6, 398-406. [CrossRef] [PubMed]

51. Reimondez-Troitiño, S.; Csaba, N.; Alonso, M.J.; de la Fuente, M. Nanotherapies for the treatment of ocular diseases. Eur. J. Pharm. Biopharm. 2015, 95, 279-293. [CrossRef]

52. Dubashynskaya, N.; Poshina, D.; Raik, S.; Urtti, A.; Skorik, Y.A. Polysaccharides in Ocular Drug Delivery. Pharmaceutics 2020, 12, 22. [CrossRef]

53. Basa, B.; Jakab, G.; Kállai-Szabó, N.; Borbás, B.; Fülöp, V.; Balogh, E.; Antal, I. Evaluation of biodegradable PVA-based 3D printed carriers during dissolution. Materials 2021, 14, 1350. [CrossRef]

54. Bhattarai, R.S.; Das, A.; Alzhrani, R.M.; Kang, D.; Bhaduri, S.B.; Boddu, S.H.S. Comparison of electrospun and solvent cast polylactic acid (PLA)/poly(vinyl alcohol) (PVA) inserts as potential ocular drug delivery vehicles. Mater. Sci. Eng. C 2017, 77, 895-903. [CrossRef]

55. Akbari, E.; Imani, R.; Shokrollahi, P.; Heidari keshel, S. Preparation of Nanoparticle-Containing Ring-Implanted Poly(Vinyl Alcohol) Contact Lens for Sustained Release of Hyaluronic Acid. Macromol. Biosci. 2021, 21, 2100043. [CrossRef]

56. Hao, J.; Wang, X.; Bi, Y.; Teng, Y.; Wang, J.; Li, F.; Li, Q.; Zhang, J.; Guo, F.; Liu, J. Fabrication of a composite system combining solid lipid nanoparticles and thermosensitive hydrogel for challenging ophthalmic drug delivery. Colloids Surfaces B Biointerfaces 2014, 114, 111-120. [CrossRef]

57. Battaglia, L.; Gallarate, M.; Serpe, L.; Foglietta, F.; Muntoni, E.; del Pozo Rodriguez, A.; Angeles Solinis Aspiazu, M. Ocular delivery of solid lipid nanoparticles. In Lipid Nanocarriers for Drug Targeting; Elsevier: Amsterdam, The Netherlands, 2018; pp. 269-312. ISBN 9780128136874.

58. Abelson, M.B.; Udell, I.J.; Weston, J.H. Normal Human Tear pH by Direct Measurement. Arch. Ophthalmol. 1981, $99,301$. [CrossRef]

59. Garcia-Valldecabres, M.; López-Alemany, A.; Refojo, M.F. pH Stability of ophthalmic solutions. Optometry 2004, 75, 161-168. [CrossRef]

60. Račić, A.; Čalija, B.; Milić, J.; Dukovski, B.J.; Lovrić, J.; Dobričić, V.; Micov, A.; Vuković, M.; Stepanović-Petrović, R.; Krajišnik, D. Formulation of olopatadine hydrochloride viscous eye drops-physicochemical, biopharmaceutical and efficacy assessment using in vitro and in vivo approaches. Eur. J. Pharm. Sci. 2021, 105906. [CrossRef]

61. Stocum, D.L. Regeneration of Epidermal Structures. Regen. Biol. Med. 2012, 1, 43-65. [CrossRef]

62. Struve, C.; Krogfelt, K.A. Role of capsule in Klebsiella pneumoniae virulence: Lack of correlation between in vitro and in vivo studies. FEMS Microbiol. Lett. 2003, 218, 149-154. [CrossRef] [PubMed]

63. Hulsart-Billström, G.; Dawson, J.I.; Hofmann, S.; Müller, R.; Stoddart, M.J.; Alini, M.; Redl, H.; El Haj, A.; Brown, R.; Salih, V.; et al. A surprisingly poor correlation between in vitro and in vivo testing of biomaterials for bone regeneration: Results of a multicentre analysis. Eur. Cells Mater. 2016, 31, 312-322. [CrossRef]

64. Zheng, Y.F.; Bae, S.H.; Huang, Z.; Chae, S.U.; Jo, S.J.; Shim, H.J.; Lee, C.B.; Kim, D.; Yoo, H.; Bae, S.K. Lack of Correlation between In Vitro and In Vivo Studies on the Inhibitory Effects of (-)-Sophoranone on CYP2C9 Is Attributable to Low Oral Absorption and Extensive Plasma Protein Binding of (-)-Sophoranone. Pharmaceutics 2020, 12, 328. [CrossRef] [PubMed]

65. Williams, C.S.; Watson, A.J.M.; Sheng, H.; Helou, R.; Shao, J.; DuBois, R.N. Celecoxib prevents tumor growth in vivo without toxicity to normal gut: Lack of correlation between in vitro and in vivo models. Cancer Res. 2000, 60, 6045-6051. 